\title{
COVID-19 infections and fatalities developments: empirical evidence for OECD countries and newly industrialized economies
}

\author{
Lucas Bretschger $^{1} \cdot$ Elise Grieg ${ }^{1} \cdot$ Paul J. J. Welfens ${ }^{2} \cdot$ Tian Xiong $^{2}$
}

Published online: 14 October 2020

C) The Author(s) 2020

\begin{abstract}
This paper presents empirical results on coronavirus infection and fatality rates from cross-country regressions for OECD economies and a sample of middle- and high-income countries. We include environmental, economic, medical, and policy variables in our analysis to explain the number of corona cases and deaths per million. We find a significant positive impact of local air pollution on infection rates in the whole sample and on fatality rates for OECD countries. Obesity rates have a positive effect on cases and deaths across the different estimation equations. The strategy of aiming to achieve herd immunity has a significant positive effect on infections as well as on death rates. The first affected countries have significantly higher mortality rates, revealing the lack of experience and medical capacity to deal with the pandemic in an initial phase. Postponing - and fighting the pandemic could save lives in many countries and generate considerable economic benefits. Other medical and policy variables discussed in the public sphere do not show a significant impact in the regression analysis. Our results suggest that improving air quality and fighting obesity helps reduce the negative effects of a coronavirus pandemic significantly. Policy options for fighting a second epidemic wave should take into account the results from this study in order to optimize global epidemic policy.
\end{abstract}

Keywords Coronavirus pandemic $\cdot$ Fatality rates - Air pollution $\cdot$ OECD countries $\cdot$ Newly industrialized countries $\cdot$ Health systems $\cdot$ Environmental policy

JEL Classification F63 $\cdot \mathrm{H} 12 \cdot \mathrm{I} 10 \cdot \mathrm{I} 18 \cdot \mathrm{Q} 53$

Paul J. J. Welfens

welfens@eiiw.uni-wuppertal.de

Extended author information available on the last page of the article 


\section{Introduction}

The coronavirus pandemic is a historical challenge for the world economy - in medical as well as economic and political terms. To achieve an understanding of the numbers of infections (cases) and fatalities from the novel coronavirus, it is crucial to have an adequate analytical framework and to come up with significant empirical results which will, of course, be relevant for economists, the business community, medical researchers and policymakers worldwide. One straightforward analytical approach is to start with a simple consideration: Negative pollution externalities are a key topic of environmental economic research - diseases, particularly communicable diseases, are another important form of negative impact on both human well-being and the economy at large. They can cause great damage, especially when they occur on a large scale, such as the recent coronavirus pandemic and the associated disease known as COVID-19. ${ }^{1}$ After its emergence in China in December 2019, the disease quickly spread around the whole world. Within a few months, governments around the globe have taken measures to combat the epidemic in their own countries - including temporary lockdowns of the population and shutdowns of certain production activities. The rapid spread of the virus in Western Europe and the US has presented an enormous test for acute care stations in hospitals where, in April and early May 2020, capacities were fully exhausted in some regions of Italy, France, Spain and the UK. ${ }^{2}$ The novel coronavirus and the disease which it has caused was initially considered to be a "pneumonia of unknown etiology" and early research identified that the underlying virus was related to the coronavirus grouping, possibly related to SARS and MERS (Sun et al. 2020). ${ }^{3}$

Successfully fighting the pandemic is of high economic relevance as the global economic costs have been estimated to be $\$ 200$ billion per week and about $\$ 80$ billion per week for the US alone, namely in the form of foregone production and extra expenditures in terms of health care system (Summers 2020). To the extent that the subsequent empirical results presented allow, in principle, to postpone the global diffusion of COVID-19 infections and thus the number of COVID-19 deaths, respectively, by at least two weeks via adequate policy measures worldwide, a combined international epidemic policy therefore would bring a global economic welfare gain of about $\$ 400$ billion - almost $1 \%$ of global Gross Domestic Product (GDP). Thus, expansionary fiscal policy could, in turn, be reduced by about $1 \%$ of GDP (assuming a multiplier in the order

\footnotetext{
${ }^{1}$ In January 2020, the World Health Organization (WHO) declared that the COVID-19 outbreak met the criteria to be classified as a "Public Health Emergency of International Concern" (WHO 2020b). On March 11, 2020, the WHO finally declared the international epidemic to be a pandemic, namely an epidemic which was now affecting countries in all regions of the world (WHO 2020c).

${ }^{2}$ Some German hospitals could accommodate a relatively small number of COVID-19 patients from Italy and France in April 2020. While the anti-epidemic policy measures in OECD countries have helped to bring down infection rates and to flatten the infection and case fatality curves over time, the cumulated number of COVID19 fatalities in some EU countries have been rather high - for example, in the UK, Italy and Spain - while Germany has recorded a rather low number of case fatalities.

${ }^{3}$ A specific problem concerns how COVID-19 case fatalities are classified where death cases in care homes presents a particular issue - the relative number of case fatalities seems to be relatively large as the elderly have higher death rates than the younger generation; in particular, the identification of a case of COVID-19 in a care home for the elderly in Belgium has the consequence all further death cases in that care home in spring and early summer 2020 were automatically classified as COVID-19 cases without further testing. Different coverage of testing across countries - including post-mortem testing - thus lead to different numbers of case fatalities.
} 
of about unity) which would bring a lower increase of the debt-GDP ratios of OECD countries and Newly Industrialized Countries as well as developing countries. The ADB has estimated that global economic losses from the pandemic could be in the range of $\$ 4.1$ trillion to $\$ 5.4$ trillion whereby economic policy intervention has been assumed to have mitigated the output loss by $30-40 \%$. As a region, Asia (the apparent origin of the pandemic) is expected to account for about 30\% of the global output loss (ADB 2020). This is the economic perspective of the subsequent empirical COVID-19 analysis - with several key economic policy implications picked up in the final section.

In the spring of 2020, it became rather clear that COVID-19 is often associated with a broader range of problems for the infected persons, namely an Acute Respiratory Distress Syndrome (ARDS). From this perspective, it is of particular interest to understand how existing respiratory problems in certain patients and the state of the environment in the form of air quality problems could possibly contribute to morbidity and mortality, respectively; this would establish a direct link between the external effects of pollution and pandemics. Other patient predispositions, such as obesity or diabetes, could also play a role. Autopsies carried out by medical researchers in Basel (Switzerland) and Hamburg (Germany), for example, have revealed that in many COVID-19 deaths, evidence was found of a critical role played by the predisposition of patients and other health problems which in the end can make the COVID-19 infection a deadly infection (ARD 2020).

Since the coronavirus pandemic stands for a novel - and rather aggressive - virus, it is clear that the availability of high quality hospital facilities, including acute care stations, could play a key role in dealing with the spreading of the virus. As regards the quality of national hospital systems, there is no clear international indicator system available with the exception of the resistance problems of patients treated in countries with a lack of differentiation in the usage of antibiotics in hospitals: MRSA-related problems (MRSA = Methicillin-Resistant Staphylococcus aureus is a group of bacteria that are genetically distinct from other Staphylococcus aureus. MRSA often is considered to be responsible for several difficult-to-treat infections amongst patients in hospitals), for example, are known to be a rather serious challenge in many hospitals; MRSA statistics could indeed be considered to be an indicator of the overall quality of national hospital systems. There is a rather short history of international comparative research on MRSA problems in hospitals (e.g., Aliberti et al. 2016). With many patients having to be admitted to hospital in the early stage of the pandemic, such structural weakness points could add to COVID-19 fatality rates.

The subsequent empirical analysis takes into account many variables in an effort to explain fatality rates; herein, some of the regression results with the most interesting findings will be presented for OECD countries as a sub-group; regression results for the overall group of countries and the Newly Industrialized Countries (NICs), respectively, are also are quite interesting and show differences across the two groups of countries. The group of OECD countries is of particular interest since many OECD countries were reaching a peak in infections and fatalities in a rather parallel fashion; but there is also the differentiation between those countries which aimed rather at achieving an early level of herd immunity - notably, Sweden, the UK and the Netherlands - and other countries which placed more emphasis on quarantine measures and social distancing as well as other selective interventions with the aim of minimizing the diffusion of the coronavirus. 
Besides the historical medical challenge, COVID-19 infections have created serious economic problems in more than 100 countries, in particular in OECD countries where the output decline in the first and second quarters of 2020 has reached double digits. The IMF (2020b) has forecasted in its World Economic Outlook that world output will decline by $4.9 \%$ in 2020 - followed by a growth rate of $5.4 \%$ in 2021; and that both OECD countries and newly industrialized countries will face serious recession pressure. The World Bank's analysis (World Bank 2020) has suggested that in the context of the corona shocks about 90 countries could face an output decline in 2020, an historical situation not seen since 1870 . One may hope that some OECD countries could manage to achieve a fast and strong economic recovery. Even if one would follow the scenario analysis of the Bank of England (2020) that the UK will have a 14\% output decline in 2020 , followed by a $15 \%$ increase of output in 2021 , the Bank's warning that the United Kingdom might witness the worst recession in 300 years naturally is a cause for concern. The impressive growth which was witnessed in China over many years came to a halt in the first quarter of 2020 when Chinese authorities were coping with the COVID-19 challenge, which seems to have emerged early on in the province of Hubei at the end of 2019. In the US, the number of unemployed has increased by more than 40 million within only twelve weeks. For certain OECD countries, the enormous expected output declines, the steep rise of deficit-GDP ratios, and the strong increase of unemployment figures (IMF 2020a, b; European Commission 2020; Pfeiffer et al. 2020) indicate an enormously negative side-effect of the coronavirus pandemic. ${ }^{4}$ While the earlier SARS and MERS epidemics where primarily regional, from an international perspective, the coronavirus pandemic is truly global and a very serious medical, social, political and economic challenge for most countries. From an economic perspective, the coronavirus pandemic is in the first instance a global symmetric shock, however, different reactions of policymakers in various countries could create differing epidemic developments across countries. The IMF World Economic Outlook of April 2020 suggested that the world economy will face an almost global recession (IMF 2020a). ${ }^{5}$ The IMF's WEO update of June 2020 suggested further weakening of international output forecasts (IMF 2020b).

The present paper provides empirical evidence on the effect of pollution on COVID19 fatality rates in middle- and high-income countries. It relates to various strands of recent literature. An early publication on the economic and health care aspects of the coronavirus pandemic is Welfens (2020a) who points to the role of health system quality and identifies theoretical aspects related to growth modelling and the structural

\footnotetext{
${ }^{4}$ It cannot be ruled out that after an initial phase of flattening the infection and death curves, there could be a second wave of infection and, in the future, a third wave of infection - until either a vaccine is available or herd immunity is achieved.

${ }^{5}$ The new pandemic is creating enormous challenges in OECD countries and the uncertainty in the early months of that pandemic makes determining adequate policy measures aimed at fighting the pandemic a difficult task: It seems that most OECD countries did not have adequate stocks of masks, disinfectants and medical personal protective equipment for the coronavirus pandemic, despite the fact that, e.g., all EU countries and Switzerland had an established official pandemic plan. Indeed, the pandemic quickly revealed weak points in many OECD countries.
} 
breakdown of the economy. ${ }^{6}$ Holtemöller (2020) develops a medium-term economic model in which an epidemic model is combined with an economic business cycle model. ${ }^{7}$ The relationship between health and the environment has been the subject of a specific literature. In an early contribution to the theory, Gutierrez (2008) uses an overlapping generations framework where pollution imposes health problems on households when they are elderly; pollution raises health costs inducing precautionary savings and capital accumulation so that the economy is more likely to be dynamically inefficient. In a similar setup, Wang et al. (2015) study precautionary savings, health insurance, and environmental policy as a response to health risks, which depend on environmental pollution; it is found that optimal environmental policies and the optimal health insurance environment are deeply intertwined. Bretschger and Vinogradova (2017) develop a stochastic framework for an endogenously growing economy, which is subject to pollution-induced health shocks and where the health status is a component of the welfare function. The paper derives closed-form analytical solutions for the optimal abatement policy and the growth rate of consumption; it shows that devoting a constant fraction of output to emissions' abatement allows for achieving the first-best allocation in the economy. Bretschger and Vinogradova (2019) generalize the concept of induced shocks to a broader class of models for endogenously growing economies and derive optimal policies to reduce the damage to households efficiently.

Turning to empirical studies, early data from case fatalities in China suggested that the elderly population experienced a higher mortality rate than the overall population (Wang et al. 2020). With respect to coronavirus-related deaths in the US, there is an early empirical analysis of case fatalities by medical researchers for US regions (Wu et al. 2020). The authors consider a battery of medical and other variables to explain regional case fatalities in the United States. ${ }^{8}$ Sherpa (2020) looks into the specific role of austerity policies on COVID-19 fatality rates and indeed finds significant evidence in the case of OECD countries for that variable. Sherpa's quantile regression analysis indicates that austerity measures in OECD countries (here, cuts to health expenditures) significantly increase the COVID-19 mortality rates in those countries. Early US medical research has pointed to the role of air quality problems for regional fatality ratios in the US (Wu et al. 2020). The COVID-19 fatality ratio is a much more serious indicator of the effects of the epidemic; the lower the average age of death, the more (hypothetical) lifetime losses are incurred - here, the US has witnessed a lower average age of death than the EU countries in the first half of 2020 (Economist 2020).

As regards COVID-19 morbidity and mortality, the medical and economic challenges in the first half of 2020 have not only been faced by the OECD countries but by NICs as

\footnotetext{
${ }^{6}$ The contribution discusses the tradable and the non-tradable sectors and considers the role of international tourism as well as some growth modelling insights (with effective labor supply in the production function negatively affected by the share of uninsured population/workers with a weaker health status). Moreover, with respect to a potential corona morbidity risk, the ratio of acute care beds relative to the population aged 65 and above is emphasized, as it seems that fatality rates are higher for the elderly.

7 The model assumes that labor input in the production function is negatively influenced by infections and COVID-19 death cases, respectively - so that welfare analysis can be applied within a hybrid economicepidemic approach.

${ }^{8}$ It is noteworthy that an online, regional COVID-19 Simulator tool was quickly developed by two research groups (Harvard Medical School researchers based at Massachusetts General Hospital and researchers from the Georgia Institute of Technology) which allows an understanding of the impact of alternative regional policy strategies in terms of soft measures versus stricter regional lockdowns.
} 
well. To the extent that NICs are also included in the research, as is the case in the subsequent analysis, it is clear that the average age of death is likely to be lower in NICs than in OECD countries where one can see a higher median age and a higher share of people above 65 years: a higher age of patients is expected to go along with a higher mortality rate for many infections and COVID-19 is a key disease here. If one is looking for statistical correlations for fatality ratios and medical variables, one should not overlook the potential case of paradoxical mortality linkages: Countries with a high share of cardiovascular patients prior to the corona shock year 2020, for example, are likely to have more intensive care units (ICUs) in hospitals than other countries - this would then be of help to such countries in facing the coronavirus epidemic as the overall number of ICUs is higher than in countries with a low share of cardiovascular patients. Subsequently, such a correlation is indeed identified and with the prevalence of diabetes, a similar link could be relevant. There are other variables which one could consider in the context of the broad perception that COVID-19 will typically seriously impact the respiratory system of infected patients: the share of smokers for instance is a variable that is sometimes discussed but, as will be shown, there is no empirical evidence of such a link.

To the extent that the limited number of OECD member countries (i.e., 37 if the recent accession country Colombia is included) - with observations in the first half of 2020 - is a problem for empirical cross-country analysis, one can consider a broader sample of countries which should include mainly NICs for which broad data are available. This is the strategy adopted in a separate subsection below which indeed identifies several medical, demographic as well as economic drivers of infections for the broader sample of countries. Moreover, as regards the narrower OECD country sample, it is possible to identify significant variables for the COVID-19 fatality ratio; these include the impact of herd immunity strategies which also turns out to be significant in the broader sample of countries. One may emphasize that by mid-2020, both OECD countries and most NICs had reached their respective national peak of COVID-19 mortality rates, while in many developing countries mortality rates still showed a clear upward trend in the WHO data (see various daily summaries of the WHO situation reports, e.g. WHO 2020a, d, e). As regards the COVID-19 incidence in terms of both morbidity and mortality, it seems that certain OECD countries were ahead of the NICs, with the exception of Brazil which, however, is a special case since President Bolsonaro had adopted a herd immunity strategy at the outset of the coronavirus pandemic. A herd immunity strategy lets one expect higher case numbers than in countries without such a strategy; however, one should also not rule out higher fatality ratios (i.e., the number of COVID-19 deaths per million inhabitants) since the herd immunity strategy could lead to an overwhelming of the capacities of intensive care units in hospitals in some or many regions - an increase of the fatality ratio will be the consequence.

As regards the structure of the respective underlying virus, SARS, MERS and COVID19 are closely related. With respect to the link between pandemics and the state of the environment, Cui et al. (2003) report a positive association between air pollution and SARS case fatality rates in the Chinese population studying 5 regions with 100 or more SARS cases. Evans and Smith (2005) examine whether serious health conditions are related to current and long-term exposure to particulate matter and ozone. The findings suggest significant current and long-term effects of air pollution exposure on new cases of heart attack, angina, chronic lung conditions, and shortness of breath. He et al. (2016) study the exogenous variations in air quality during the 2008 Beijing Olympic Games and find that a 
$10 \%$ decrease in PM10 concentrations reduces the mortality rate by $8 \%$. Deryugina et al. (2019) estimate the causal effects of acute fine particulate matter exposure on mortality, health care use, and medical costs among the US elderly using Medicare data. They use changes in local wind direction as an instrument and machine learning to estimate the lifeyears lost due to pollution exposure. The paper finds that mortality effects are concentrated in about $25 \%$ of the population of elderly residents. In a quantitative cohort study conducted between 2000 and 2018 in six US metropolitan regions, Wang et al. (2019) find that longterm exposure to ambient air pollutants is significantly associated with increasing health problems in particular emphysema and worsening lung function. Summarizing previous empirical findings, Conticini et al. (2020) conclude that individuals living in areas with high levels of air pollution are more prone to developing chronic respiratory conditions, which partly explains a higher prevalence and lethality of novel, highly contagious, viral pandemics such as COVID-19 in those regions.

Our paper builds on these contributions and tests the main empirical hypotheses with novel data for COVID-19 fatality rates in different sets of countries. The empirical analysis on the country level has to consider the heterogeneities between the countries which we accommodate by inclusion of appropriate control and dummy variables. We chose the OECD countries as our first sample because these economies are quite similar in basic aspects of development, institutions, and COVID history. Our second sample includes Newly Industrialized and other Middle Income Countries, which increases the number of observations. We highlight that a study at country level offers a number of advantages compared to a study at regional level. First, one key variable of concern, air pollution, has a larger variation for countries which benefits the accuracy of the results. Second, pollution is mainly driven by policy choices, e.g. concerning energy and transportation systems, which are mainly taken at the national level. Political decisions are exogenous in our setup so that the need for instrumenting the pollution variable is not imminent. Third, we are able to study the impact of pollution jointly with the effects of health status, health and other policy, as well as economic conditions, which are all determined on the country level providing a broader perspective than analyses for single countries. Key drivers of infections are per capita income and air quality problems, while main drivers of fatality ratios in OECD countries are air pollution, obesity and the herd immunity variable; slowing down new infections and the spreading of the coronavirus can save lives - if our findings for 104 countries would apply to the overall world economy, a one week postponing of infections would save 183,624 lives globally.

In the subsequent analysis, we first take a closer look at measurement aspects of infection cases and fatality rates in OECD countries as well as in selected NICs (Section 2). Section 3 develops the basic hypothesis for the subsequent empirical models and describes the data series. In Section 4, we present the regression results for OECD countries and, separately, for the larger country sample. Section 5 concludes with policy conclusions and perspectives for further research.

\section{Corona case fatalities: Descriptive statistics and data problems in an international perspective}

The basic idea, based on the previous discussion and the literature, respectively, is to analyze the link between case fatality rates related to the novel coronavirus and a selection 
of exogenous variables which should include medical, demographic and environmental factors plus other data. As a first step, one has to consider the measurement of fatalities from COVID-19 where several varying sources and methodologies exist.

There are three different approaches to measuring fatalities from COVID-19 cases, namely (i) the Johns Hopkins University (JHU) approach covering different data sources (JHU 2020), (ii) the WHO measurement approach based on the official governmental reports of the member countries, and (iii) the excess mortality estimates that indirectly attempt to measure COVID-19 deaths. For (ii) we have to note the differences in the measurement of COVID-19 deaths between different regions and institutions, even within individual countries. For (iii), excess mortality figures are available from EuroMOMO, which is a network covering 24 countries/regions in Europe. ${ }^{9}$ One important policy perspective here could be to assess the need for international and intra-country (regional) political solidarity based on excess case fatalities if there are different international or regional classifications/coverage of COVID-19 fatalities. ${ }^{10}$ The concept of excess fatalities, i.e. the difference between the actual numbers of deaths in a certain period compared to the number one could normally expect for the same period could be a useful measurement tool for covering COVID-19 fatalities in an international environment in which countries' COVID-19 fatalities statistics are not harmonized. There is, however, the problem of data availability and indeed a need that the OECD and the UN would provide harmonized excess mortality statistics. ${ }^{11}$

Additionally, national statistical coverage might be different at the beginning of the epidemic and in the later peak stage where for practical reasons the coverage could change; e.g., with acute care capacities in hospitals overwhelmed and a lack of sufficient testing kits available, the testing for COVID-19 patients who die at home or in care homes will be rather incomplete at that particular stage of the epidemic. If countries are all close to or immediately beyond peak fatality - with a logistical curve relevant for infections and case fatalities, respectively - no major problem with a comparative analysis of case fatalities should occur since countries' fatalities and case fatality rates are in the upper, flat, part of the logistical curve. In the EuroMOMO bulletin for week 18 (late April 2020), the authors note for the European countries covered: "The excess mortality estimated by the EuroMOMO over the past weeks appears to have peaked in all countries by now." (2020a, p.1). From this perspective, a regression analysis of cumulated case fatalities in western and eastern European countries at the end of May should be adequate; one may also assume that the US peak in case fatality rates had been

\footnotetext{
${ }^{9}$ In the EuroMOMO (2020a) Bulletin of week 18, 2020, key findings are summarized as follows: (i) "...overall excess mortality is driven by a very substantial excess mortality in some countries, while other countries have had no excess mortality. The mortality excess is primarily seen in the age group of $>=65$ years, but also in the age group of 15-64 years" and (ii) the EuroMOMO (2020b) Bulletin of week 19 shows that England had the highest excess mortality in week 17, 2020, while Germany, for example - actually Berlin and Hesse as two possibly representative German states - showed no excess mortality in the whole first quarter of 2020. Germany officially had about 7000 Corona case fatalities by late April. This makes clear that replacing WHO data by excess mortality figures also can have its problems. The Italian statistical office (ISTAT 2020) has calculated regional excess case fatalities which, unsurprisingly, show considerable variation across regions.

${ }^{10}$ The UK is an interesting case since the coverage in Scotland, for example, in March 2020 was broader than that in England and Wales.

${ }^{11}$ Manski and Molinari (2020) highlight the absence of bounds on infection rates and explain the logical problem of bounding them; they find that the actual infection rates might be substantially higher than reported.
} 
achieved in May 2020. To the best knowledge of the authors, no OECD country is still expecting a peak in case fatality rates in summer 2020 .

As regards the number of infected persons, the WHO and the Johns Hopkins University coronavirus research group (Dong et al. 2020) report slightly different numbers of COVID-19 case fatalities. ${ }^{12}$ Differences are explained by the fact that the WHO relies on national governments' reported fatality numbers while the Johns Hopkins University also takes into consideration press reports on case fatalities (JHU 2020). All reported data naturally contain a lag of about a week since testing and test result reporting as well as death reporting brings delays. Our subsequent analysis will, however, not look at the death rate of a single day - as reported by authorities, the WHO and the JHU, respectively; rather we are interested in explaining the cumulated case fatalities associated with COVID-19. To the extent that epidemics typically follow a logistical curve - with the number of patients recovering (R'; assumed to have immunity against the virus) being a barrier to the further spread of infections - there is a theoretical problem in comparing death rates across countries to the extent that the start of the respective national epidemics show large lags across countries. As regards lags in OECD countries, one may assume that the enormously dense flight and travel networks, respectively, will bring smaller time lags across countries. It should also be mentioned that as long as the absolute number of infections is small, the contact tracing of infected persons is obviously relatively easy so that an early detection of the outbreak and massive tracing and quarantine measures could strongly bend down the infection curves - see, e.g., the Republic of Korea and Taiwan. In the OECD countries, only Iceland appears to be a country where early testing and government intervention seems to have brought a particularly favorable situation in terms of infection intensity (infections - as officially measured - relative to population).

Fatality rates (measured by deaths per million of population (population figures for 2018)) differ considerably across the OECD countries, see Fig. 1; in most OECD countries, the peak in terms of fatality rates had apparently been reached by the end of June, 2020. It is clear that Belgium is leading concerning the fatality rate among the OECD countries since April this year. Meanwhile, the death ratios of COVID-19 in the UK, France, and the US rise consistently. Although both Spain and Italy still have very high fatalities, the curves have become flatter in mid-2020. Looking at the growth trend from the graph and complementary statistics, countries of particular concern are Chile and Mexico, their death rates have soared since the beginning of June. Figure 2 below shows that the majority of the selected NICs generally have lower fatality ratios than OECD countries, but since late April 2020 experienced a rapid increase, especially in Peru, Brazil and Mexico; most of the countries in the top 9 list (NICs) are from South America.

The results for OECD countries indicate considerable differences in fatalities. In the subsequent ranking of countries (see Table 1) one can see that on the basis of fatality rates at late July 2020, the top five countries were Belgium, the UK, Spain, Italy and Sweden, followed by France, Chile, and the US. The five best performing countries were (in descending order) Japan, South Korea, the Slovak Republic, Australia, and New Zealand. Among the big economies with a rather favorable record in Europe - and

\footnotetext{
12 The definition of a COVID-19 fatality according to the WHO (2020d) is as follows: "COVID-19 death is defined for surveillance purposes as a death resulting from a clinically compatible illness in a probable or confirmed COVID-19 case, unless there is a clear alternative cause of death that cannot be related to COVID disease (e.g. trauma). There should be no period of complete recovery between the illness and death."
} 
Fig. 1 Fatality Rates in OECD Countries (cumulated COVID-19 fatalities until 20 July 2020, per million population in 2018)

\section{COVID-19 Fatality Rates of OECD Countries}
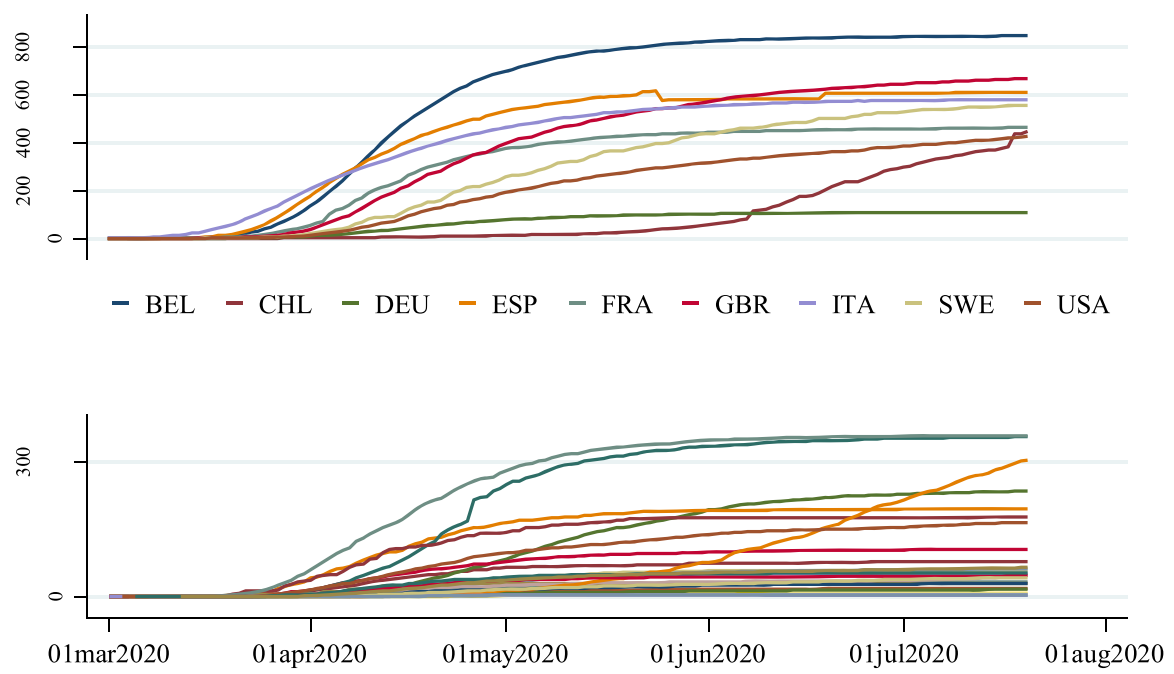

Other OECD Countries

Note: The top 8 plus Germany are listed in alphabetical order, BEL(Belgium), CHL(Chile), DEU(Germany), ESP(Spain), FRA(France), GBR(United Kingdom), ITA(Italy), SWE(Sweden), USA(United States)

Source: Own representation using data available from Our World in Data

with high levels of international trade and tourism linkages, including with China - is Germany, ranked 17, whose fatality ratio was around 1/4 of that of the US (two months prior the ratio was $1 / 2$ ). Three ranking places behind Germany are Denmark, Austria and Turkey; the latter's fatality ratio is only about $1 / 13$ of that of Belgium. Press reports (see, e.g., Beisel 2020) have argued that Belgium's death rate is particularly high since care homes with one COVID-19 fatality will record all subsequent mortality cases without testing - as being linked to COVID-19. We also listed the ranking of a group of selected NICs in Table 2. Peru, Brazil, Mexico, and Ecuador are the top 4, and these countries all have above 300 fatalities per million population, the rate of deadly cases in Ecuador is almost twice that of the following country Iran. Brazil, as a big country in Latin America, and Iran, as a big country (in terms of population figure) in Asia, have fatality ratios that are slightly below that of the United States and roughly the same as Portugal, respectively. Russia is close to the fatality ratio of Austria. China, where the 
Fig. 2 Fatality Rates in Selected NICs (cumulated COVID-19 fatalities until 20 July 2020, per million population in 2018)

COVID-19 Fatality Rates of Selected NICs
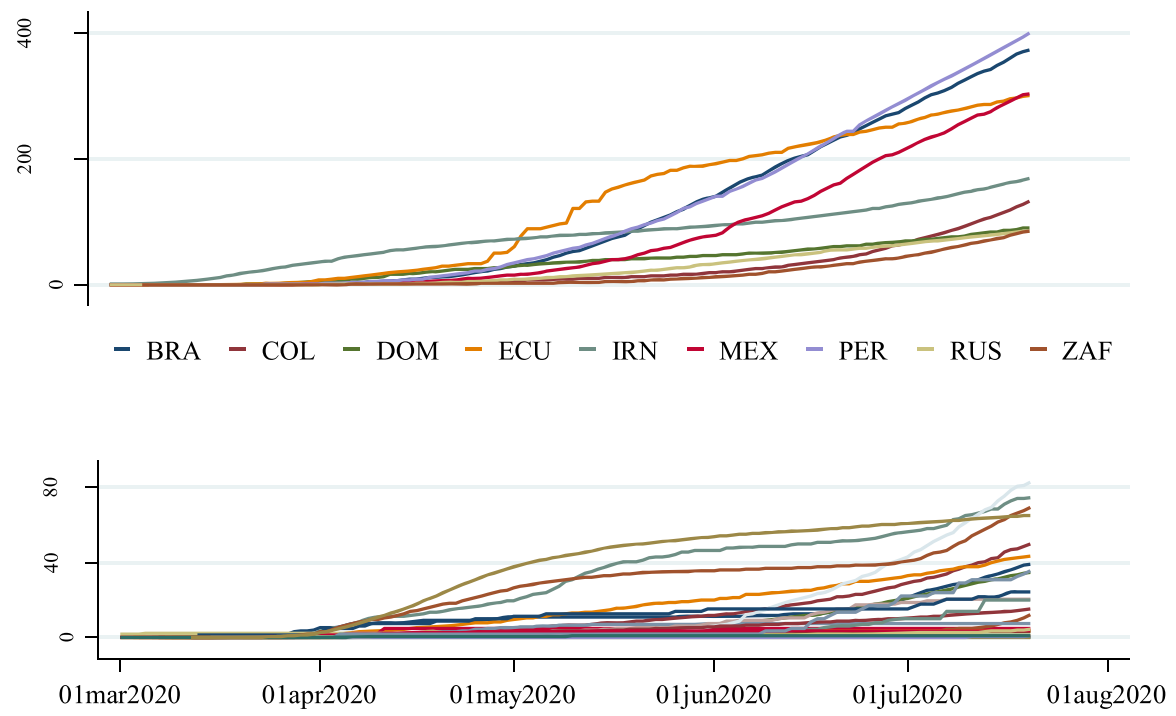

Other Selected NICs

Note: Top 9 NICs are listed in alphabetical order, BRA(Brazil), COL(Colombia), DOM(Dominican Republic), ECU(Ecuador), IRN(Iran), MEX(Mexico), PER(Peru), RUS(Russia), ZAF(South Africa).

Source: Own representation using data available from Our World in Data

novel coronavirus emerged, kept the fatality rate below 5 per million. In any case, it is remarkable that countries show considerable differences in terms of fatality rates. Given the fact that hospitals and acute care beds, respectively, are less available in NICs than in OECD countries, and one may assume that NICs might have some underreporting of fatality ratios, but so far there is no evidence from comparative research on this issue.

Certain EU countries with very high fatality ratios have at some point suffered critical situations in terms of acute care capacities in hospitals as is witnessed by the relocation of COVID-19 hospital patients from Italy and France to Germany. Among the countries covered in the graph and the table above, Sweden, with its rather liberal epidemic policy with limited lockdowns imposed on Swedish families early on - does not show a favorable performance in the field of COVID-19 fatalities; Sweden, the Netherlands and the UK are three countries which placed an early emphasis on herd immunity. One cannot easily argue that countries with high fatality rates have been strict in early lockdown measures and shutdowns, respectively. Among the countries with rather low fatality rates, Greece is 
Table 1 COVID-19 Fatality rates in OECD countries (cumulated COVID-19 fatalities until 20 July 2020, per million population in 2018)

\begin{tabular}{|c|c|c|c|c|c|c|c|c|}
\hline Rank & Country & $\begin{array}{l}\text { Fatalities } \\
\text { per mn }\end{array}$ & Rank & Country & $\begin{array}{l}\text { Fatalities } \\
\text { per mn }\end{array}$ & Rank & Country & $\begin{array}{l}\text { Fatalities } \\
\text { per mn }\end{array}$ \\
\hline 1 & Belgium & 845.59 & 14 & Luxembourg & 177.32 & 27 & Poland & 42.91 \\
\hline 2 & United Kingdom & 667.3 & 15 & Portugal & 165.64 & 28 & Czech Republic & 33.52 \\
\hline 3 & Spain & 607.85 & 16 & Colombia & 132.38 & 29 & Lithuania & 29.39 \\
\hline 4 & Italy & 579.62 & 17 & Germany & 108.45 & 30 & Iceland & 29.3 \\
\hline 5 & Sweden & 556.38 & 18 & Denmark & 105.49 & 31 & Greece & 18.61 \\
\hline 6 & France & 461.93 & 19 & Austria & 78.94 & 32 & Latvia & 16.44 \\
\hline 7 & Chile & 444.81 & 20 & Turkey & 65.11 & 33 & Japan & 7.79 \\
\hline 8 & United States & 424.57 & 21 & Hungary & 61.7 & 34 & South Korea & 5.77 \\
\hline 9 & Netherlands & 357.69 & 22 & Finland & 59.2 & 35 & Slovakia & 5.13 \\
\hline 10 & Ireland & 355.02 & 23 & Slovenia & 53.39 & 36 & Australia & 4.78 \\
\hline 11 & Mexico & 303.91 & 24 & Estonia & 52.02 & 37 & New Zealand & 4.56 \\
\hline 12 & Canada & 234.54 & 25 & Israel & 47.25 & & & \\
\hline
\end{tabular}

Source: Own representation using data available from Our World in Data

remarkable as a country which imposed strict regulatory quarantine measures rather early on. A systemic approach requires a broad econometric analytical approach.

Table 2 COVID-19 Fatality rates in selected NICs countries (cumulated COVID-19 fatalities until 20 July 2020, per million population in 2018)

\begin{tabular}{|c|c|c|c|c|c|c|c|c|}
\hline Rank & Country & $\begin{array}{l}\text { Fatalities } \\
\text { per mn }\end{array}$ & Rank & Country & $\begin{array}{l}\text { Fatalities } \\
\text { per mn }\end{array}$ & Rank & Country & $\begin{array}{l}\text { Fatalities } \\
\text { per mn }\end{array}$ \\
\hline 1 & Peru & 399.95 & 13 & Turkey & 65.11 & 25 & Belize & 5.03 \\
\hline 2 & Brazil & 373.96 & 14 & Argentina & 49.70 & 26 & Paraguay & 4.35 \\
\hline 3 & Mexico & 303.91 & 15 & Bulgaria & 43.18 & 27 & Malaysia & 3.80 \\
\hline 4 & Ecuador & 301.14 & 16 & Albania & 38.92 & 28 & Georgia & 3.76 \\
\hline 5 & Iran & 168.92 & 17 & Suriname & 35.80 & 29 & Jamaica & 3.38 \\
\hline 6 & Colombia & 132.38 & 18 & Azerbaijan & 34.91 & 30 & China & 3.23 \\
\hline 7 & Dominican Republic & 90.43 & 19 & Guyana & 24.16 & 31 & Namibia & 1.18 \\
\hline 8 & South Africa & 84.86 & 20 & Gabon & 20.67 & 32 & Jordan & 1.08 \\
\hline 9 & Russia & 84.57 & 21 & Kazakhstan & 19.97 & 33 & Thailand & 0.83 \\
\hline 10 & Guatemala & 82.89 & 22 & Indonesia & 15.15 & 34 & Botswana & 0.43 \\
\hline 11 & Bosnia and Herzegovina & a 74.68 & 23 & Costa Rica & 12.17 & 35 & Fiji & 0.00 \\
\hline 12 & Serbia & 69.37 & 24 & Cuba & 7.68 & & & \\
\hline
\end{tabular}

Source: Own representation using data available from Our World in Data 
Based on our assessment of fatality and excess fatality rates in OECD countries, we choose to use COVID-19 death rates in the empirical part, holding the COVID-19 case rates constant. This reflects the heterogeneous standards of measurement in the different countries as well as the random spread of the pandemic between the countries. In principle, to have the infection rates instead of the case rates would be preferable but these figures are unfortunately biased and unreliable. It turns out that the most important predictor for the number of deaths is the number of cases. Hence, when attempting to estimate the impacts that health and environmental variables have on the number of deaths, we therefore include the number of cases in order to avoid omitted variable bias and improve the precision of our results.

\section{Empirical model and data}

\subsection{Deaths}

Explaining epidemic fatalities is a rather difficult challenge - certainly with a limited sample of data. Among the key variables to be considered are predispositions in the various OECD countries' populations and possibly influences relevant to the respiratory system. This potentially includes, for example, air quality aspects and thus crucial environmental aspects.

The choice of the dependent variable is not straightforward. While one is typically interested in the infection fatality rate, i.e. the ratio of deaths to infections, this number is unreliable, especially in an ongoing pandemic. This is due to the difficulty in accurately estimating the number of infections in a cross-country perspective, as different countries have varying testing regimes. Here, we choose to focus on the death rate per million as there is less variation in how deaths from COVID-19 are tested and reported across countries. However, as different countries were affected to differing degrees by the virus due to a combination of luck and successful policies, the death rate per million is not necessarily informative on its own. To get around this issue, we include the reported number of cases by country in all our regressions, as keeping the number of cases constant allows for a more informative comparison of the factors that affect deaths per million. Finally, we include an alternative specification using the average growth rate of the total deaths across the sample period. We are aware that even the measurement of cases involves some differences between countries, which leads us to interpret our results with caution.

Our main independent variable of interest is pollution, specifically PM2.5. Our first choice for this variable is exposure in the largest functional urban area (FUA). In most countries, the virus hit large cities the hardest so most victims of the virus would be living in the largest city or in cities that are very similar in terms of air quality. However, this variable is not available for the all countries. Five OECD countries are missing this variable, along with the extended sample of non-OECD countries. The alternative variables are mean exposure to PM2.5 for the whole country, and exposure in the largest available city. We recognize that there may be endogeneity associated with the use of pollution, in particular there might be confounding variables in terms of population density and economic activity. We have not found a convincing instrument 
that works on a cross-country level, so we cannot claim that our results are causal. However, we deal with issues of omitted variable bias by including a selection of control variables described below. However, our results may be reporting correlations rather than causal relationships, and should be interpreted with caution.

To control for other potential factors affecting the lungs, we also include the percentage of smokers in each country. A priori it is not clear what effect we should expect from this variable, as smoking has also been linked to lower case fatality of COVID-19.

More recent insights from corona fatalities show that fatality rates are higher for the elderly, and that COVID-19 attacks the blood circulatory system and related cells in addition to the respiratory system. Being overweight has also been suggested as a risk factor in COVID-19. The health condition of the population at large thus appears to be an important factor, and we therefore control for the population aged 65 and above in the largest FUA or median age, the percentage share of the population that is overweight, the death rate from cardiovascular disease and the prevalence of diabetes.

Furthermore, predisposition factors in the health system could play a role. There could be weak points in the availability of adequate personal protective equipment for medical personnel and care personnel in nursing homes. We therefore include the number of hospital beds per 1000 as a proxy for the quality of the health care system in the extended sample due to a high correlation with the overweight variable in OECD countries. In robustness checks (see in Appendix Tables 11 and 12), we also used findings of the Global Health Security (GHS) Index in both samples, but find less convincing results. We also include the percentage of smokers in each country to control for other potential factors affecting lung capacity and health, thus leading to a higher risk of respiratory infections. However, a priori it is not clear what effect we should expect from this variable, as smoking has also been linked to lower case fatality of COVID-19, and according to a review report from WHO until end of June, the impact from smoking is contradicted in existing studies (2020g).

Policy response is an important factor in determining the impact of the virus. However, high fatality rates more or less force the government to adopt strict shutdown and lockdown measures, since otherwise the intensive care capacities in hospitals would quickly be overwhelmed. This risk always exists once the so-called $\mathrm{R}$ infection factor exceeds unity ( $\mathrm{R}$ indicates a critical parameter of the spreading function of the virus). With $\mathrm{R}>1$, the system moves to an exponential virus diffusion function as one infected person will infect more than one other person so that it is only a question of time until hospital capacities are exceeded. When successful, such measures reduce the transmission rates and the number of cases which, in turn, lowers the death rate per million. While most of the policy response would be captured in the number of cases, we do include variables to control for policy responses. In the main regression, we include a dummy for whether a country adopted a herd immunity policy at the start of the pandemic, with two alternative variables: the mean value of the policy stringency response as reported by Our World in Data (OWID), as well as the speed of the policy response as measured by the number of days between the date the first 10 cases were reported and the date on which the country implemented travel restrictions. 
As there is an important element of learning over time from the virus, we assume that countries hit by the crisis earlier might see higher deaths than those affected later. We therefore include a variable indicating the number of days from January 1 st until the first case was recorded in a country (for some countries this number is negative).

\subsection{Cases}

As particulate matter can facilitate the spread of a virus (there are links between PM2.5 and precipitation as well as other meteorological variables - see, e.g., the study on New York by Adhikari and Yin 2020) we also look at whether pollution has an effect on the number of cases per million, and the average growth rate of the total cases during the sample period. In determining the number of cases, economic, demographic and policy responses are likely more important than health factors. We therefore control for more country specific issues than when looking at the number of deaths. We include GDP per capita to control for income level. While richer countries may generally be better equipped to tackle a pandemic, COVID-19 has hit rich countries earlier. Furthermore, richer countries tend to have higher mobility, which can facilitate the spread of the virus. We therefore expect a positive sign on GDP per capita. As the virus will spread faster in more densely populated areas, we include population density. As policy response is key in containing the spread of the virus, we include the herd immunity dummy as well as the speed of the policy response.

Finally, we include selected health variables. We reason that a less healthy population will likely have a higher number of more severe cases, thus recording a larger fraction of the cases. For the OECD sample, due to the low number of observations, we only include the fraction of smokers and of overweight people. In the full sample we add the cardiovascular disease (CVD) death rate and the diabetes prevalence, as well as the timing of the outbreak of the pandemic in each country.

\subsection{Sample}

To facilitate comparison across countries, we use World Bank classifications to exclude countries defined as low income and as fragile/in conflict. In robustness checks, we consider the subsamples of high and upper middle income countries, as well as OECD only. The pandemic hit OECD and higher income countries earlier, so these countries may be further along the infection curve. A list of countries included in each sample can be found in the Appendix in Table 10.

The variables are described in the following Table 3, with summary statistics in Table 4. A correlation matrix is included in the Appendix (Table 9).

Overall, we believe our choice of sample allows us to make informative observations, and that our variables cover important sources of omitted variable bias. However, the small sample size and the cross-sectional nature of the study leaves room for future researchers to expand on our methodology. Once the pandemic has run its course, researchers will be able to extend the sample size and adopt more complex methodologies, thus allowing for more conclusive evidence on the causality of the relationships documented in this paper. 
Table 3 Description of the Variables

\begin{tabular}{|c|c|c|c|c|}
\hline Variables & Description & Source & $\begin{array}{l}\text { Expected } \\
\text { sign }\end{array}$ & Time period \\
\hline $\begin{array}{l}\text { Deaths per } \\
\text { million }\end{array}$ & $\begin{array}{l}\text { Total deaths attributed to } \\
\text { COVID-19 per million people }\end{array}$ & OWID & & 31.12.2019-20.07.2020 \\
\hline $\begin{array}{r}\text { Cases per } \\
\text { million }\end{array}$ & $\begin{array}{l}\text { Total confirmed cases of } \\
\text { COVID-19 per million people }\end{array}$ & OWID & + & 31.12.2019-20.07.2020 \\
\hline $\begin{array}{l}\text { Avg. growth } \\
\text { rate, deaths }\end{array}$ & $\begin{array}{l}\text { Average growth rate of } \\
\text { COVID-19 deaths }\end{array}$ & OWID & & 31.12.2019-20.07.2020 \\
\hline $\begin{array}{l}\text { Avg. growth } \\
\text { rate, cases }\end{array}$ & $\begin{array}{l}\text { Average growth rate of } \\
\text { COVID-19 cases }\end{array}$ & OWID & & 31.12.2019-20.07.2020 \\
\hline $\begin{array}{l}\text { PM2.5 in } \\
\text { largest FUA }\end{array}$ & $\begin{array}{l}\text { Mean exposure to PM2.5 } \\
\text { in the largest functional urban area }\end{array}$ & WHO & + & 2017 \\
\hline $\begin{array}{l}\text { PM } 2.5 \\
\quad \text { Exposure }\end{array}$ & $\begin{array}{l}\text { Mean annual exposure to PM2.5 } \\
\text { (micrograms per cubic meter) }\end{array}$ & $\begin{array}{l}\text { World } \\
\text { Bank }\end{array}$ & + & 2017 \\
\hline $\begin{array}{l}\text { PM2.5 in most } \\
\text { populous city }\end{array}$ & $\begin{array}{l}\text { PM2.5 exposure in the most } \\
\text { populous city available }\end{array}$ & WHO & + & 2017 \\
\hline Median age & $\begin{array}{l}\text { The median age of the population, } \\
\text { UN projection for } 2020\end{array}$ & OWID & + & Latest year available \\
\hline $\begin{array}{l}\text { Percent over } 65 \text {, } \\
\text { largest FUA }\end{array}$ & $\begin{array}{l}\text { The share of the population aged } \\
65 \text { and above in the largest } \\
\text { functional urban area }\end{array}$ & WHO & + & 2017 \\
\hline $\begin{array}{l}\text { Percent } \\
\text { overweight }\end{array}$ & $\begin{array}{l}\text { Estimated share of the population } \\
\text { that is overweight }\end{array}$ & WHO & + & 2016 \\
\hline Percent smokers & $\begin{array}{l}\text { The average percentage of male } \\
\text { and female smokers }\end{array}$ & OWID & \pm & Latest year available \\
\hline $\begin{array}{l}\text { Diabetes } \\
\text { prevalence }\end{array}$ & $\begin{array}{l}\text { Diabetes prevalence (\% of population } \\
\text { aged } 20 \text { to } 79 \text { ) }\end{array}$ & OWID & + & 2017 \\
\hline CVD Death rate & $\begin{array}{l}\text { The death rate from cardiovascular } \\
\text { disease }\end{array}$ & OWID & + & 2017 \\
\hline $\begin{array}{l}\text { Hospital beds/ } \\
\text { thousand }\end{array}$ & Hospital beds per 1000 people & OWID & - & Latest year available \\
\hline GHS Index & $\begin{array}{l}\text { The overall score of the Global Health } \\
\text { Security Index }(0-100,100=\text { highest } \\
\text { score })\end{array}$ & $\begin{array}{l}\text { GHS } \\
\text { Index } \\
2019\end{array}$ & - & 2019 \\
\hline $\begin{array}{l}\text { Herd immunity } \\
\quad \text { policy }\end{array}$ & $\begin{array}{l}\text { A dummy variable equal to } 1 \text { if a } \\
\text { country applies the herd immunity } \\
\text { policy (UK, Sweden, Netherlands, } \\
\text { and Brazil) }\end{array}$ & $\begin{array}{l}\text { News } \\
\text { items* }\end{array}$ & + & 2020 \\
\hline $\begin{array}{l}\text { Days until first } \\
\text { case }\end{array}$ & $\begin{array}{l}\text { The number of days from } 1 \text { st January } \\
\text { until the first case was recorder, own } \\
\text { calculation }\end{array}$ & OWID & - & 01.01.2020-20.07.2020 \\
\hline $\begin{array}{l}\text { Days until intl. } \\
\text { Travel } \\
\text { control }\end{array}$ & $\begin{array}{l}\text { Days from first } 10 \text { cases until any } \\
\text { international travel controls issued, } \\
\text { own calculation }\end{array}$ & OxCGRT & - & 01.01.2020-20.07.2020 \\
\hline $\begin{array}{r}\text { Mean Policy } \\
\text { stringency }\end{array}$ & $\begin{array}{l}\text { Mean of stringency index from } \\
\text { the first date data available to } \\
\text { 20th July } 2020\end{array}$ & OxCGRT & - & 01.01.2020-20.07.2020 \\
\hline GDP per capita & $\begin{array}{l}\text { Gross domestic product at } \\
\text { purchasing power parity }\end{array}$ & OWID & + & Latest year available \\
\hline
\end{tabular}


Table 3 (continued)

\begin{tabular}{lllll}
\hline Variables & Description & Source & $\begin{array}{l}\text { Expected Time period } \\
\text { sign }\end{array}$ & \\
\hline $\begin{array}{c}\text { Population } \\
\text { density }\end{array}$ & $\begin{array}{l}\text { Number of people divided by } \\
\text { international dollars) } \\
\text { land area, measured in square } \\
\text { kilometers }\end{array}$ & OWID & + & Latest year available \\
\hline
\end{tabular}

OWID uses the data from the European Centre for Disease Prevention and Control (ECDC), OxCGRT represents the Oxford Covid-19 Government Response Tracker (Hale et al. 2020). Covariates included in the OWID dataset are from several sources, see: https://github.com/owid/covid-19data/blob/master/public/data/owid-covid-data-codebook.md

*For the Netherlands, see the speech by Prime Minister Mark Rutte on March 16, 2020: https:/www. government.nl/documents/speeches/2020/03/16/television-address-by-prime-minister-mark-rutte-of-thenetherlands; for Sweden, see public comments from the country's chief epidemiologist Anders Tegnell https://www.svd.se/tegnell-flockimmunitet-inte-huvudtaktiken?fbclid=IwAR0ESWZX8S_ QbSWcnSCKGaHxhnw_gBxTxn88CsHwoAWOMlCB7i1BhDTIPPI; for the United Kingdom, comments from the United Kingdom's Chief Scientific Adviser Sir Patrick Vallance: https://www.ft.com/content/38 a81588-6508-11ea-b3f3-fe4680ea68b5. The article from Bhatt and Parikh on the website of the abcNews news network (https://abcnews.go.com/US/vaccine-reach-herd-immunity-scientists/story?id=71662733) provides information about herd immunity policy in Brazil, the Netherlands, and Sweden (2020)

Source: Own representation

Table 4 Summary Statistics

\begin{tabular}{|c|c|c|c|c|c|}
\hline & $\mathrm{N}$ & Mean & St.Dev & $\min$ & $\max$ \\
\hline Deaths per million & 132 & 102.5 & 188.37 & 0 & 1237.55 \\
\hline Cases per million & 132 & 3156.73 & 4967.14 & 2.61 & $37,016.93$ \\
\hline Average growth rate of deaths & 122 & 5.71 & 3.03 & 0 & 25 \\
\hline Average growth rate of cases & 132 & 8.08 & 2.67 & 1.91 & 16 \\
\hline PM2.5 in largest FUA & 32 & 13.59 & 5.63 & 5.8 & 25.3 \\
\hline PM2.5 air pollution, mean annual exposure & 147 & 23.95 & 17.76 & 5.86 & 99.73 \\
\hline PM2.5 in most populous city available & 84 & 25.33 & 19.03 & 5 & 92 \\
\hline Percent over 65, largest FUA & 32 & 16.46 & 3.32 & 7.93 & 23.86 \\
\hline Median age & 127 & 33.58 & 8.11 & 16.8 & 48.2 \\
\hline Percent overweight & 143 & 52.11 & 15.76 & 18.3 & 87.9 \\
\hline Percent smokers & 109 & 22.28 & 8.89 & 4 & 43.65 \\
\hline Diabetes prevalence & 131 & 8.11 & 3.98 & .99 & 22.02 \\
\hline Death rate from CVD & 129 & 236.11 & 119.08 & 79.37 & 724.42 \\
\hline Hospital beds/thousand & 118 & 3.29 & 2.34 & .3 & 13.05 \\
\hline GHS index & 139 & 44.95 & 14.02 & 16.2 & 83.5 \\
\hline Days from Jan 1 until first case & 131 & 60.62 & 19.62 & 13 & 136 \\
\hline Herd immunity policy & 136 & .03 & .17 & 0 & 1 \\
\hline Days until travel restrictions, from 10 cases & 129 & -18.59 & 37.36 & -118 & 147 \\
\hline Mean policy stringency & 135 & 46.09 & 9.26 & 8.06 & 67.02 \\
\hline GDP per capita & 127 & $24,278.45$ & $21,031.96$ & 2064.24 & $116,935.6$ \\
\hline Population density & 132 & 297.46 & 973.63 & .14 & 7915.73 \\
\hline Observations & 132 & & & & \\
\hline
\end{tabular}




\section{Empirical results}

\subsection{OECD countries}

\subsubsection{Deaths}

The results of our empirical analyses for OECD countries are reported in Table 5, where a range of regression equations explaining fatality rates are considered. In column (1), we include health variables, while in column (2) we add policy variables. In column (3), we show alternative policy variables. In columns (4) and (5) we report alternative specifications: column (4) indicates the results of using the mean pollution exposure variable, thus extending our sample to 37, while column (5) reports the results when the growth rate of the deaths is the outcome variable.

The effect of pollution is positive and significant at the $10 \%$ level or below in each regression, except for the growth rate of deaths and use the mean policy stringency in model 3. However, due to the small sample size, it is not surprising that the precision of the results is somewhat variable. The results indicate that an increase of $1 \mu \mathrm{g} / \mathrm{m} 3 \mathrm{PM} 2.5$ in the mean exposure to PM2.5 in the largest city is associated with an increase in deaths per million of around 10. However, while our results generally show that an increase in PM2.5 concentration appears to be associated with a higher number of deaths from COVID-19, the results are not highly robust to alternative specifications (not reported). Further research on a larger sample, ideally with a higher spatial resolution, is also required before one can conclude that an increase in pollution causes a higher fatality rate from COVID-19. However, our regressions do indicate that higher pollution is associated with more COVID-19 fatalities.

In terms of the controls, we find that total cases per million are associated with a higher number of deaths per million, which is not surprising (Table 5). One more case is associated with around 0.03 more deaths per million in a country. A large elderly population in the largest city is associated with a higher number of deaths, but the results are not statistically significant. The overweight variable is also statistically significant except for specification (3), and it has the expected positive sign. The sign of the percent of smokers is inconsistent and statistically insignificant. The death rate from CVD has an unexpected negative sign, statistically significant in all regressions with the exception of specification (3). While we cannot say with certainty why this is, there are several potential explanations: e.g., countries with a high number of CVD deaths in the past may have more Acute Intensive Care units, or higher CVD death rates means that there are fewer at-risk individuals left in the population. Diabetes prevalence also appears insignificant, except in columns (1) and (5), where the results seem to indicate that a higher prevalence of diabetes is associated with a higher growth rate of the deaths. The number of hospital beds also appears to be insignificant. Note that the small sample size works against the precision of these results, and thus they should not be taken as clear evidence that none of these variables affect COVID-19 death rates.

Of the policy variables, the herd immunity policy variable appears the strongest: it is statistically significant, and the coefficient is large. A country that initially pursued a policy of herd immunity appears to have around 225-255 more deaths per million than other countries, as well as a 2.2 percentage points higher average growth rate. Travel restrictions appear not to significantly affect the 
Table 5 OECD, COVID-19 Deaths

\begin{tabular}{|c|c|c|c|c|c|}
\hline & (1) & (2) & (3) & (4) & $(5)$ \\
\hline & $\begin{array}{l}\text { Deaths per } \\
\text { million }\end{array}$ & $\begin{array}{l}\text { Deaths per } \\
\text { million }\end{array}$ & $\begin{array}{l}\text { Deaths per } \\
\text { million }\end{array}$ & $\begin{array}{l}\text { Deaths per } \\
\text { million }\end{array}$ & $\begin{array}{l}\text { Avg. growth rate, } \\
\text { deaths }\end{array}$ \\
\hline Variables & OECD & OECD & OECD & OECD & OECD \\
\hline PM2.5 in largest FUA & $\begin{array}{l}10.46^{*} \\
(5.17)\end{array}$ & $\begin{array}{l}11.43^{* * *} \\
(4.54)\end{array}$ & $\begin{array}{l}6.38 \\
(5.72)\end{array}$ & & $\begin{array}{l}0.02 \\
(0.03)\end{array}$ \\
\hline $\begin{array}{l}\text { PM2.5 air pollution, mean } \\
\text { annual exposure }\end{array}$ & & & & $\begin{array}{l}12.16^{*} \\
(7.03)\end{array}$ & \\
\hline Cases per million & $\begin{array}{l}0.03 * * \\
(0.01)\end{array}$ & $\begin{array}{l}0.03 * * \\
(0.01)\end{array}$ & $\begin{array}{l}0.03 * * \\
(0.01)\end{array}$ & $\begin{array}{l}0.03 * * \\
(0.01)\end{array}$ & \\
\hline Percent over 65, largest FUA & $\begin{array}{l}5.10 \\
(7.29)\end{array}$ & $\begin{array}{l}0.97 \\
(7.94)\end{array}$ & $\begin{array}{l}2.73 \\
(7.70)\end{array}$ & $\begin{array}{l}3.29 \\
(9.08)\end{array}$ & $\begin{array}{l}0.01 \\
(0.06)\end{array}$ \\
\hline Percent overweight & $\begin{array}{l}10.44 * * * \\
(3.16)\end{array}$ & $\begin{array}{l}11.19 * * * \\
(3.42)\end{array}$ & $\begin{array}{l}7.29 \\
(4.35)\end{array}$ & $\begin{array}{l}11.44 * * \\
(4.13)\end{array}$ & $\begin{array}{l}0.12^{* * *} \\
(0.03)\end{array}$ \\
\hline Percent smokers & $\begin{array}{l}-5.46 \\
(6.49)\end{array}$ & $\begin{array}{l}-1.41 \\
(5.77)\end{array}$ & $\begin{array}{l}-1.45 \\
(5.28)\end{array}$ & $\begin{array}{l}-1.41 \\
(6.48)\end{array}$ & $\begin{array}{l}0.06 \\
(0.06)\end{array}$ \\
\hline Death rate from CVD & $\begin{array}{l}-1.15 * * \\
(0.49)\end{array}$ & $\begin{array}{l}-0.73 * \\
(0.36)\end{array}$ & $\begin{array}{l}-0.41 \\
(0.37)\end{array}$ & $\begin{array}{l}-0.74 * \\
(0.37)\end{array}$ & $\begin{array}{l}-0.01 * * * \\
(0.00)\end{array}$ \\
\hline Diabetes prevalence & $\begin{array}{l}-31.41^{*} \\
(17.54)\end{array}$ & $\begin{array}{l}-22.76 \\
(19.41)\end{array}$ & $\begin{array}{l}-19.75 \\
(18.48)\end{array}$ & $\begin{array}{l}-24.11 \\
(22.21)\end{array}$ & $\begin{array}{l}0.38 * * * \\
(0.13)\end{array}$ \\
\hline $\begin{array}{l}\text { Days from Jan } 1 \text { until first } \\
\text { case }\end{array}$ & & $\begin{array}{l}-4.02 * * \\
(1.76)\end{array}$ & $\begin{array}{l}-3.76^{* *} \\
(1.67)\end{array}$ & $\begin{array}{l}-4.14 * * \\
(1.85)\end{array}$ & $\begin{array}{l}-0.04 * * \\
(0.02)\end{array}$ \\
\hline Herd immunity policy & & $\begin{array}{l}229.97 * * * \\
(78.34)\end{array}$ & $\begin{array}{l}255.21 * * * \\
(86.89)\end{array}$ & $\begin{array}{l}224.83 * * \\
(85.82)\end{array}$ & $\begin{array}{l}2.20 * * * \\
(0.67)\end{array}$ \\
\hline $\begin{array}{l}\text { Days until travel restrictions, } \\
\text { from } 10 \text { cases }\end{array}$ & & $\begin{array}{l}-0.55 \\
(0.85)\end{array}$ & & $\begin{array}{l}-0.61 \\
(0.90)\end{array}$ & \\
\hline Mean policy stringency & & & $\begin{array}{l}8.81 * * \\
(3.94)\end{array}$ & & \\
\hline Constant & $\begin{array}{l}-226.23 \\
(222.57)\end{array}$ & $\begin{array}{l}-263.59 \\
(234.97)\end{array}$ & $\begin{array}{l}-442.33^{*} \\
(226.43)\end{array}$ & $\begin{array}{l}-303.28 \\
(250.76)\end{array}$ & $\begin{array}{l}-1.38 \\
(2.38)\end{array}$ \\
\hline Observations & 32 & 32 & 32 & 32 & 32 \\
\hline R-squared & 0.56 & 0.69 & 0.71 & 0.68 & 0.69 \\
\hline
\end{tabular}

Robust standard errors in parentheses

$* * * p<0.01, * * p<0.05, * p<0.1$

number of deaths. In column (3), we introduce the mean policy stringency variable as a control, while dropping the herd immunity policy control. Policy stringency appears to be statistically significant. There is one potential caveat: the stringency of policy could be endogenous to both the severity of the outbreak and the fatality rate: A harder hit country might introduce very strict regulations once the true nature of the threat has been acknowledged. One may emphasize that the OECD should provide full data coverage for all countries - with only 32 of the 37 OECD countries giving the relevant data there is a critical lack of data. Moreover, the OECD would be wise to contribute to collecting excess fatality data for all its member countries in a timely manner. 


\subsubsection{Cases}

We explore the relationship between pollution and the number of cases for OECD countries in Table 6. In column (1), we include basic country-level characteristics of GDP (per capita GDP, purchasing power parity) and population density; it is not surprising to see that per capita income has a positive impact on infection numbers (see column (1) in the table for cases in OECD countries) since a higher income goes along with more international trade contacts and international tourism contacts which in turn typically raise the probability of internationally transmitted epidemic infection. In column (2), we introduce policy variables, and in column (3), we add the health controls. Column (5) reports the results from using the alternative PM2.5 variable on the full OECD sample, and column (6) shows results from looking at the average growth rate of the cases.

Table 6 OECD, COVID-19 Cases

\begin{tabular}{|c|c|c|c|c|c|}
\hline & (1) & (2) & (3) & (4) & (5) \\
\hline & $\begin{array}{l}\text { Cases per } \\
\text { million }\end{array}$ & $\begin{array}{l}\text { Cases per } \\
\text { million }\end{array}$ & $\begin{array}{l}\text { Cases per } \\
\text { million }\end{array}$ & $\begin{array}{l}\text { Cases per } \\
\text { million }\end{array}$ & $\begin{array}{l}\text { Avg. growth } \\
\text { rate, cases }\end{array}$ \\
\hline Variables & OECD & OECD & OECD & OECD & OECD \\
\hline PM2.5 in largest FUA & $\begin{array}{l}194.2 \\
(241.8)\end{array}$ & $\begin{array}{l}286.4 \\
(266.2)\end{array}$ & $\begin{array}{l}217.3 \\
(201.7)\end{array}$ & & $\begin{array}{l}0.063 \\
(0.0836)\end{array}$ \\
\hline PM2.5 air pollution, mean annual exposure & & & & $\begin{array}{l}107.5 \\
(95.43)\end{array}$ & \\
\hline GDP per capita & $\begin{array}{l}0.107 * * * \\
(0.037)\end{array}$ & $\begin{array}{l}0.089 \\
(0.056)\end{array}$ & $\begin{array}{l}0.095 \\
(0.0714)\end{array}$ & $\begin{array}{l}0.044 \\
(0.041)\end{array}$ & $\begin{array}{l}3.24 \mathrm{e}-05 \\
(2.57 \mathrm{e}-05)\end{array}$ \\
\hline Population density & $\begin{array}{l}-7.404 \\
(6.989)\end{array}$ & $\begin{array}{l}-12.71 \\
(8.730)\end{array}$ & $\begin{array}{l}-8.015 \\
(8.581)\end{array}$ & $\begin{array}{l}-3.641 \\
(7.138)\end{array}$ & $\begin{array}{l}0.008 \\
(0.007)\end{array}$ \\
\hline Days from Jan 1 until first case & & $\begin{array}{l}-39.98 \\
(34.36)\end{array}$ & $\begin{array}{l}-55.70 \\
(43.15)\end{array}$ & $\begin{array}{l}-33.78 \\
(36.16)\end{array}$ & $\begin{array}{l}0.001 \\
(0.017)\end{array}$ \\
\hline Herd immunity policy & & $\begin{array}{l}2736 \\
(1955)\end{array}$ & $\begin{array}{l}2280 \\
(2667)\end{array}$ & $\begin{array}{l}618.1 \\
(2004)\end{array}$ & $\begin{array}{l}-0.806 \\
(1.972)\end{array}$ \\
\hline Days until travel restrictions, from 10 cases & & $\begin{array}{l}25.91 \\
(19.96)\end{array}$ & $\begin{array}{l}12.61 \\
(23.14)\end{array}$ & $\begin{array}{l}25.96 \\
(20.56)\end{array}$ & $\begin{array}{l}-0.008 \\
(0.012)\end{array}$ \\
\hline Percent over 65, largest FUA & & & $\begin{array}{l}-265.4 \\
(296.4)\end{array}$ & & $\begin{array}{l}-0.067 \\
(0.088)\end{array}$ \\
\hline Percent overweight & & & $\begin{array}{l}75.93 \\
(86.14)\end{array}$ & $\begin{array}{l}106.0 \\
(68.88)\end{array}$ & $\begin{array}{l}0.143 * * \\
(0.064)\end{array}$ \\
\hline Percent smokers & & & $\begin{array}{l}123.8 \\
(162.1)\end{array}$ & $\begin{array}{l}5.875 \\
(105.6)\end{array}$ & \\
\hline Constant & $\begin{array}{l}-2543 \\
(3281)\end{array}$ & $\begin{array}{l}-846.4 \\
(4282)\end{array}$ & $\begin{array}{l}-3467 \\
(5569)\end{array}$ & $\begin{array}{l}-4341 \\
(3691)\end{array}$ & $\begin{array}{l}-2.437 \\
(3.753)\end{array}$ \\
\hline Observations & 32 & 32 & 32 & 37 & 32 \\
\hline R-squared & 0.139 & 0.256 & 0.339 & 0.195 & 0.364 \\
\hline
\end{tabular}

Robust standard errors in parentheses

$* * * \mathrm{p}<0.01, * * \mathrm{p}<0.05, * \mathrm{p}<0.1$ 
The coefficient of the pollution variable shows a large positive effect of pollution, however the results are not statistically significant in any specification. Indeed, while the variables generally have the expected sign, most of the variables in Table 6 are not statistically significant. As the small sample size does not allow us to say with any certainty whether the lack of strong results is due to the small sample or due to the relationships between the variables being non-existent, we increase the sample size by adding other middle and high income countries.

\subsection{Middle and high-income countries}

\subsubsection{Deaths}

We report the results for the regression on cases in Table 7 In the first column, we report the results when controlling for population health, while in column (2) we include country characteristics and policy variables and include regional dummies. In column (3), we use the alternative pollution variable, pollution in the largest city, and in column (4) we restrict the sample to richer countries, column (5) removes lower middle income countries.

The results of the deaths are ambiguous. In most specifications, we cannot detect a significant relationship, and the coefficient is negative. Using the alternative PM2.5 variable, while still not statistically significant, does show a positive association with deaths. Finally, the growth rate of deaths appears to have a positive correlation with the PM2.5. The results thus do not strongly support the results from the OECD counties. A potential explanation for the significant sign of PM2.5 in OECD countries could be that the life expectancy in OECD countries is higher than in middle-income countries - if there is a kind of long-term "fatigue effect" on the respiratory system, PM2.5 could indeed play a critical role in OECD countries here.

Unsurprisingly, the number of cases has a positive and significant effect on the number of deaths across all specifications. The point estimate indicates that increasing the cases per million by 1 increases the number of deaths by about 0.01 .

The effects of the health variables are somewhat surprising. Neither the share of smokers nor the median age appears to have a significant impact on deaths. Median age appears to have a negative effect on the average growth rate of deaths. Both prevalence of cardiovascular disease (CVD) and diabetes appear with a negative sign when significant. However, neither result is consistent across specifications. Percent of overweight people appears to increase the deaths per million, although this variable is only significant in some specifications.

Preparedness of the health care system measured as beds per 1000, appears to lower the number of deaths by about 10 per extra bed, but the results are not statistically significant. We also used GHS indices as alternative measurements of the quality of the health care system. The results are not shown, but the coefficients for the overall GHS score as well as relevant sub-indices were negative and statistically insignificant. The herd policy variable appears to be important as it is statistically significant in all regression results, and the coefficient is large. A country that initially pursued a policy of herd immunity seems to have between 
Table 7 Full sample, COVID-19 Deaths

\begin{tabular}{|c|c|c|c|c|c|}
\hline \multirow{3}{*}{ Variables } & (1) & (2) & (3) & (4) & (5) \\
\hline & $\begin{array}{l}\text { Deaths per } \\
\text { million }\end{array}$ & $\begin{array}{l}\text { Deaths per } \\
\text { million }\end{array}$ & $\begin{array}{l}\text { Deaths per } \\
\text { million }\end{array}$ & $\begin{array}{l}\text { Deaths per } \\
\text { million }\end{array}$ & $\begin{array}{l}\text { Avg. growth } \\
\text { rate, deaths }\end{array}$ \\
\hline & full sample & full sample & full sample & $\begin{array}{l}\text { U. middle \& } \\
\text { High income }\end{array}$ & full sample \\
\hline \multirow{2}{*}{$\begin{array}{l}\text { PM2.5 air pollution, mean } \\
\text { annual exposure }\end{array}$} & -0.915 & -0.800 & & -1.607 & $0.021 *$ \\
\hline & $(0.716)$ & $(0.770)$ & & $(1.786)$ & $(0.012)$ \\
\hline \multirow{2}{*}{$\begin{array}{l}\text { PM2.5 in most populous city } \\
\text { available }\end{array}$} & & & 0.697 & & \\
\hline & & & $(0.879)$ & & \\
\hline \multirow[t]{2}{*}{ Cases per million } & $0.010 * *$ & $0.008^{* *}$ & $0.0147 * * *$ & $0.008 *$ & \\
\hline & $(0.005)$ & $(0.004)$ & $(0.005)$ & $(0.004)$ & \\
\hline \multirow[t]{2}{*}{ Median age } & 1.719 & -4.887 & -6.732 & -4.466 & $-0.116^{*}$ \\
\hline & $(2.292)$ & $(4.368)$ & $(5.885)$ & $(4.926)$ & $(0.059)$ \\
\hline \multirow[t]{2}{*}{ Percent overweight } & $2.127 * *$ & 1.973 & $4.564 *$ & 2.744 & $0.065 * * *$ \\
\hline & $(0.937)$ & $(1.376)$ & $(2.333)$ & $(2.261)$ & $(0.017)$ \\
\hline \multirow[t]{2}{*}{ Percent smokers } & 0.112 & 1.771 & 1.361 & 1.898 & 0.034 \\
\hline & $(1.675)$ & $(1.719)$ & $(2.208)$ & $(2.376)$ & $(0.030)$ \\
\hline \multirow[t]{2}{*}{ Death rate from CVD } & $-0.257 * *$ & -0.186 & -0.146 & $-0.329 * *$ & -0.001 \\
\hline & $(0.104)$ & $(0.117)$ & $(0.150)$ & $(0.155)$ & $(0.002)$ \\
\hline \multirow[t]{2}{*}{ Diabetes prevalence } & $-9.840 * *$ & -3.510 & -8.876 & 0.267 & $-0.110^{* *}$ \\
\hline & $(3.808)$ & $(3.569)$ & $(7.402)$ & $(4.489)$ & $(0.055)$ \\
\hline \multirow[t]{2}{*}{ Hospital beds/thousand } & & -6.113 & -7.030 & -8.458 & 0.097 \\
\hline & & $(7.910)$ & $(9.519)$ & $(8.985)$ & $(0.117)$ \\
\hline \multirow[t]{2}{*}{ Herd immunity policy } & & $230.3 * * *$ & $188.6^{* * * *}$ & $222.7 * * *$ & $3.310 * * *$ \\
\hline & & $(56.77)$ & $(59.36)$ & $(63.85)$ & $(0.948)$ \\
\hline \multirow{2}{*}{$\begin{array}{l}\text { Days until travel restrictions, } \\
\text { from } 10 \text { cases }\end{array}$} & & 0.539 & 0.521 & & \\
\hline & & $(0.384)$ & $(0.521)$ & & \\
\hline \multirow{2}{*}{$\begin{array}{l}\text { Days from Jan } 1 \text { until first } \\
\text { case }\end{array}$} & & $-3.082 * *$ & $-4.767 * *$ & $-4.641 * * *$ & $-0.0467 * * *$ \\
\hline & & $(1.193)$ & $(1.890)$ & $(1.596)$ & $(0.013)$ \\
\hline \multirow[t]{2}{*}{ Constant } & 55.29 & $299.8 * *$ & $320.6^{*}$ & 301.2 & $8.369 * * *$ \\
\hline & $(56.70)$ & (139.6) & (191.7) & (193.0) & $(1.590)$ \\
\hline Observations & 108 & 104 & 75 & 77 & 98 \\
\hline R-squared & 0.337 & 0.576 & 0.627 & 0.586 & 0.336 \\
\hline Region dummies & $\mathrm{NO}$ & YES & YES & YES & $\mathrm{NO}$ \\
\hline
\end{tabular}

Robust standard errors in parentheses

$* * * \mathrm{p}<0.01, * * \mathrm{p}<0.05, * \mathrm{p}<0.1$

190 and 250 more deaths per million than other countries, and a 3 percentage points higher growth in deaths.

Finally, the date of the first case appears quite important: pushing back the arrival of the virus by just one day - or a week - is associated with fewer deaths per million. The implication is that effective WHO communication strategies of early warning systems about the new virus were of crucial importance as were national policy measures to 
slow down the spreading of the virus nationally and internationally in the first half of 2020.

Overall, our empirical results point to a tentative conclusion that there may be an adverse effect of pollution and exposure to PM2.5 on the severity of the COVID-19 pandemic. However, the results presented above are subject to several limitations, and should be interpreted with caution. Due to data constraints in an ongoing pandemic, we rely on cross-sectional variation, thus we are unable to establish the causality of the relationships. Further, there are likely measurement errors in both the number of cases and deaths, and we do not know whether these are random or if they introduce significant bias in our results. Future research should take care to establish causality and use alternative and updated numbers for the deaths and the cases - including using excess mortality rather than the reported mortality. Still, we continue below with the policy implications of the results, noting that further research is necessary for stronger conclusions to be drawn.

\subsubsection{Cases}

We report the results for the regression on cases in Table 8. In the first column, we report the results when controlling for population health, while in column (2), we include country characteristics and policy variables and include regional dummies. In column (3), we use the alternative pollution variable, pollution in the largest city, and in column (4), we restrict the sample to richer countries, column (5) removes lower middle income countries.

The number of cases seems to increase with exposure to PM2.5. The coefficient is large and positive in all specifications, ranging from 40 to 150 more cases per million when mean exposure to PM2.5 is increased by $1 \mu \mathrm{g} / \mathrm{m} 3$ PM2.5. In absolute terms, this means that if Italy reduced its average pollution exposure to the level of Finland (from around 15 to around 5), the country could have seen roughly between 25 and 90,000 fewer cases. The results are statistically significant when controlling for the full set of covariates, as well as when restricting the sample to upper middle income and high income countries in columns and when looking at the average growth rate.

Interestingly, the median age of the population appears with a negative sign and statistically significant in the full regression. Here, increasing the age of the population by 1 year is associated with a fall in the number of cases by more than 130. It is possible that the higher mortality rate among older people makes them more likely to heed social distancing guidelines, thus reducing the total number of cases. A similar explanation could be posited for the negative effect of CVD deaths. However, when including economic and policy variables, the effect of CVD disappears.

The share of overweight people appears to increase the total number of cases while statistically significant. However, the effect disappears when including regional dummies, possibly due to the regional variation of obesity. The other health variables appear to not play a large role in the spread of the virus.

Of the country characteristics, we see that GDP has a significant positive effect on the number of cases. This is not surprising as the virus hit rich countries in Europe and North America first, and the effect may well disappear when the virus 
Table 8 Full sample, COVID-19 Cases

\begin{tabular}{|c|c|c|c|c|c|}
\hline \multirow{3}{*}{ Variables } & (1) & (2) & (3) & (4) & (5) \\
\hline & $\begin{array}{l}\text { Cases per } \\
\text { million }\end{array}$ & $\begin{array}{l}\text { Cases per } \\
\text { million }\end{array}$ & $\begin{array}{l}\text { Cases per } \\
\text { million }\end{array}$ & Cases per million & $\begin{array}{l}\text { Avg. growth } \\
\text { rate, cases }\end{array}$ \\
\hline & full sample & full sample & full sample & $\begin{array}{l}\text { U. middle \& High } \\
\text { income }\end{array}$ & full sample \\
\hline \multirow{2}{*}{$\begin{array}{l}\text { PM2.5 air pollution, mean } \\
\text { annual exposure }\end{array}$} & $93.91 *$ & $82.87 *$ & & $153.5 *$ & $0.048 * * *$ \\
\hline & $(52.02)$ & $(47.26)$ & & $(85.59)$ & $(0.014)$ \\
\hline \multirow{2}{*}{$\begin{array}{l}\text { PM2.5 in most populous city } \\
\text { available }\end{array}$} & & & $43.42 *$ & & \\
\hline & & & $(25.80)$ & & \\
\hline \multirow[t]{2}{*}{ Median age of the population } & -66.74 & $-130.1^{*}$ & $-267.3 * * *$ & -152.3 & -0.05 \\
\hline & $(78.03)$ & $(72.35)$ & $(95.44)$ & $(95.68)$ & $(0.046)$ \\
\hline \multirow[t]{2}{*}{ Percent overweight } & $143.1 * * *$ & -15.34 & $120.6 * * *$ & 35.67 & $0.065^{* * *}$ \\
\hline & $(38.84)$ & $(38.93)$ & $(36.61)$ & $(46.06)$ & $(0.020)$ \\
\hline \multirow[t]{2}{*}{ Percent smokers } & -35.95 & 57.63 & 93.84 & 96.63 & -0.003 \\
\hline & $(73.88)$ & $(80.18)$ & $(94.29)$ & $(106.4)$ & $(0.035)$ \\
\hline \multirow[t]{2}{*}{ Death rate from CVD } & $-11.00^{* * *}$ & -0.727 & -10.01 & -0.647 & -0.003 \\
\hline & $(4.034)$ & $(4.554)$ & $(6.266)$ & $(5.895)$ & $(0.002)$ \\
\hline \multirow[t]{2}{*}{ Diabetes prevalence } & 142.4 & -4.058 & $298.4^{*}$ & -90.38 & -0.083 \\
\hline & $(90.67)$ & $(101.3)$ & $(169.3)$ & $(138.3)$ & $(0.060)$ \\
\hline \multirow[t]{2}{*}{ GDP per capita } & & $0.156^{* * * *}$ & $0.0547 *$ & $0.144 * * *$ & $1.48 \mathrm{e}-05$ \\
\hline & & $(0.056)$ & $(0.029)$ & $(0.050)$ & $(1.23 \mathrm{e}-05)$ \\
\hline \multirow[t]{2}{*}{ Population density } & & 0.154 & $0.733 *$ & 0.257 & $-5.32 \mathrm{e}-06$ \\
\hline & & $(0.608)$ & $(0.434)$ & $(0.470)$ & $(0.0002)$ \\
\hline \multirow[t]{2}{*}{ Herd immunity policy } & & $3357^{*}$ & 2990 & $3656 * *$ & 1.335 \\
\hline & & $(1742)$ & (1921) & $(1723)$ & $(0.939)$ \\
\hline \multirow{2}{*}{$\begin{array}{l}\text { Days until travel restrictions, } \\
\text { from } 10 \text { cases }\end{array}$} & & $-23.00 *$ & 0.454 & -19.58 & -0.004 \\
\hline & & $(12.52)$ & $(10.50)$ & $(12.35)$ & $(0.006)$ \\
\hline \multirow{2}{*}{$\begin{array}{l}\text { Days from Jan } 1 \text { until first } \\
\text { case }\end{array}$} & & -16.21 & -28.24 & -34.54 & 0.021 \\
\hline & & $(26.08)$ & $(23.16)$ & $(35.59)$ & $(0.014)$ \\
\hline \multirow[t]{2}{*}{ Constant } & -1961 & -1168 & 2712 & -2964 & $5.021 * * *$ \\
\hline & $(2845)$ & (3377) & $(2582)$ & $(5775)$ & $(1.673)$ \\
\hline Observations & 108 & 106 & 75 & 77 & 106 \\
\hline R-squared & 0.361 & 0.599 & 0.517 & 0.683 & 0.285 \\
\hline Region dummies & NO & YES & NO & NO & NO \\
\hline
\end{tabular}

Robust standard errors in parentheses

$* * * \mathrm{p}<0.01, * * \mathrm{p}<0.05, * \mathrm{p}<0.1$

runs its course in the lower income countries. It should be considered that high per capita income countries tend to have both relatively strong international trade and investment relations (including) and rather elevated levels of international tourism activities - both with respect to international tourism abroad and with respect to incoming foreign tourists; hence a higher per capita income and higher virus 
spreading intensity will go together which explains the link between per capita income and infections.

The results of the policy variables are surprising. The herd immunity policy has a large coefficient - a country initially pursuing herd immunity has more than 3000 more cases per million than other countries, significant in columns (3) and (4). If these results were causal, the magnitude for a country like Sweden, with a population of 10 million and 80,000 cases, 30,000 cases (or 37.5\%) might have been due to the initial herd immunity policy. It should be noted that the herd immunity finding is crucial not just in a medical perspective; higher infection numbers in herd immunity countries such as the UK, the Netherlands and Sweden could also bring about stronger output declines which in turn undermine economic recovery in these countries as well as trading partners due to potential spillover effects. However, while the countries that followed herd immunity at first appear somewhat arbitrary and thus potentially random, more research needs to be done to fully establish this as a causal relationship.

While the speed of any international travel controls appears to reduce the number of cases, the result is only statistically significant at the $10 \%$ level in the full sample with regional dummies. Results are similar for other policy variables (e.g., time until stay at home orders or the cancellation of public events), and are not reported. Similarly, we find no effect of the speed at which the virus first appeared in a country on the total number of cases.

As regards the results for the full sample in Table 8, one should consider: In all four of the models (1) to (4), air quality problems are significant drivers of infections; in two of these four equations, obesity and the herd immunity variable show a significant impact. In three of the four equations, the per capita income variable is significant for higher infections (recall that per capita income, based on PPP figures, can be considered to be a proxy for international contact intensity). Overweight is also significant in column (5) for the growth rate of infections. As regards the obesity variables in high income countries and low income countries, one should keep in mind that in relatively poor countries, being underweight is rather the more pressing problem in terms of health system challenges and as per capita income and the weight of both children and adults are rising, health care expenditures are also rising (Bansal and Zilberman 2020) so that one should avoid a simplistic interpretation of the obesity variable in the various models. The more low income countries are included, the more important problems related to being underweight - again, in relatively poor countries a frequent problem - will be part of a broad full sample group: In both Tables 7 and 8 - the former referring to COVID-19 fatality ratios - the obesity variable is significant in the regression in column (3) for the rather small group of 75 countries (higher and middle income group) while the overweight variable is no longer significant in the enlarged group of 104 countries of column (2) in Table 7 and in the group of 106 countries group of column (2) in Table 8 .

Looking at the main fatality results for the full sample in Table 7 , the cases are significant in all equations and the herd immunity variable always has a positive significant effect on fatalities, while postponing the international diffusion of the corona virus (variable: days from Jan. 1 until first case) always has a negative impact. 


\section{Policy conclusions and research perspectives}

The economic logic of the above empirical findings is that an epidemic policy of countries which slows down the international diffusion of the virus brings high benefits in terms of lower fatalities as well as in terms of economic welfare gains. Policy measures which slow down the pandemic are crucial as one can expect both a positive effect in terms of saving lives and a positive welfare effect from lower output losses and avoiding extra health care expenditures. Based on the sample of 104 countries in Table 7, a one (or two) week slowing down of the global epidemic would save 183,624 (or 367,249) lives if one assumes that the parameter estimated also applies to the world economy $(3.082$ cases $/ 1$ million $* 7$ days $* 7.8$ billion world population $=$ $168,277.2$, for country details see Table 13 in the Appendix); the 104 countries cover $79 \%$ of global output (the global death toll was reported to be 686,703 on August 3, 2020 (WHO 2020f)). Without entering a debate on the economic value of human life, it is clear that changes in fatality figures are politically relevant and the massive public investment in vaccination programs in $\mathrm{OECD} / \mathrm{G} 20$ countries clearly reflect the political sensitivity of COVID-19 fatality numbers. At the same time, it is rather remarkable how low-profile the herd immunity policy debate in Sweden, the Netherlands, the UK and Brazil has been in the first half of 2020 - given the clear finding that a herd immunity policy raises the fatality ratios as shown in the empirical section.

To the extent that national epidemic policy measures help to slow down the international spread of the virus, and thus help reducing, for example, extra health care expenditures (related inter alia to testing and covering the hospital stays of COVID-19 patients) but also bring about output losses (e.g., from quarantine measures in the respective country), there is a certain economic trade-off of anti-pandemic policy measures. The only exception would be national vaccination programs as such programs would give protection directly to the persons vaccinated and indirectly lead to a reduced probability of non-vaccinated people in the respective country and its major trading partners (where trading includes, of course, international tourism). To the extent that neighboring countries with early vaccination programs generate relatively strong positive external effects, for example for adjacent countries, it might be possible to obtain an effective level of herd immunity via vaccination for both countries combined even if one of the countries considered has a critical share of people resisting a vaccination; in a post-vaccination scenario, the relatively high share of foreign tourists from France or Italy, for example, in Germany could contribute to herd immunity in Germany if the share of people vaccinated in France or Italy exceeds that of people living in Germany.

For the coronavirus pandemic, and indeed similar future epidemics, one can draw the conclusion that policy measures aimed at curbing the number of overweight persons in the population should be a key element of a consistent strategy aiming to reduce fatality ratios; moreover, air quality problems have also been identified as crucial problems so that sustainability policy could be considered to be a critical element of epidemic policy as well. As policymakers in the EU have emphasized the need to combine economic recovery programs in the corona shock year of 2020 and in the following years with a particular emphasis on enhanced climate policy and sustainability policy, respectively - see the results from the EU summit in Brussels in July 2020 (European Council 2020) - one may argue that 
part of such measures could be expected to reduce PM 2.5 air quality problems and thus should help people to live with the coronavirus more easily in the future; a more explicit emphasis on reducing air quality problems, however, seems to be adequate in Europe, the UK, the US and Newly Industrialized Countries in the future. Fighting obesity could have become an immediate new policy priority in EU/OECD/G20 countries once the first empirical results for COVID-19 fatalities in OECD countries had been published (Bretschger et al. 2020). One could still could start an OECD-wide or G-20 anti-obesity program - beyond the soft standard WHO projects - in late 2020, and indeed within a few months some successful intermediate targets could be achieved, thereby reducing global fatality rates. Such a program would generate extra benefits in many high income countries to the extent that happiness indicators are typically negatively linked to obesity in general; obesity also reduces life expectancy in high income countries (Bansal and Zilberman 2020). There is some risk that in developing countries where certain problems related to undernourishment already existed in 2019 - the corona shock-related economic crisis of 2020 has reinforced these existing underweight problems in this group of countries.

A lack of efficient international policy co-operation has been a problem in sustainability and climate protection policy - the mechanism of international inefficiency encountered here could have a partial mirror image in epidemic policy. Herd immunity policy cannot be recommended. Governments eager to avoid high fatality ratios should try to postpone the arrival and spreading of the coronavirus, respectively. As regards vaccination as a potential way to stop the pandemic, one should emphasize that vaccination has an element of a positive national or international - external effect, namely that not only the person who accepts the risks of a vaccination and indeed gets vaccinated is protected but they also help to protect other people from falling ill with the coronavirus; this interesting aspect cannot be covered here, but it matters to the extent that adequate subsidization of R\&D for a new vaccine and of vaccination, respectively, could help to stop the pandemic in the medium term and thus to make herd immunity approaches indeed obsolete.

To the extent that higher per capita income represents an internationally more open economy and society, one may argue - unsurprisingly - that economic prosperity might go along with a higher health risk. Without further research one should, however, not overemphasize this aspect since medical progress in the sense of developing new vaccinations or new pharmaceutical products (i.e. new chemical formulations which are more effective in fighting the pandemic disease) could also be facilitated by more international trade and investment linkages. One should also not rule out that higher per capita income is associated with more legal and illegal immigration - with immigrant workers often living in rather crowded housing conditions facing a high risk of infections and infections in the immigrant community will often spread amongst the larger community. In this context, one may point to one key observation regarding the Spanish Flu of 1918/19 (Spinney 2017, chapter 15): The fact that so many people died in some of the wealthiest quarters of Paris was a puzzle for scientists until they understood exactly who it was who was dying - the high income families in these quarters would typically employ domestic servants who 
often lived in a separate part of the house in crowded living conditions which facilitated the spread of the disease amongst the employed personnel (almost one quarter of the fatality cases were maids working for wealthy families). As regards COVID-19 infections and fatalities, more research on the social dimension is needed in the future.

The coronavirus pandemic raises key questions from a medical, economic and political perspective. If there is to be some international solidarity, the international community could decide to allocate particular help to those countries with a high number of fatalities per million. While the regression model looks at fatalities in OECD countries and selected NICs, the next steps in research will be to include more countries, if possible all UN countries; a necessary step for broad policy recommendations in the context of a global pandemic. The reflections presented are thus only part of a broader analytical effort which in the end should not overlook critical links between medical and economic dynamics in an international pandemic. Countries with both high infection rates and high numbers of COVID-19 deaths have obviously suffered particularly negative shocks in production, namely to the extent that there was an infection-related decline of production, the effective labor input has reduced, or that strict regulatory shutdowns and lockdowns were imposed by government that were designed to fight the epidemic but brought the side effect of a negative supply and a negative (aggregate) demand shock. Given the simple fact that fatalities differ so much across OECD countries and NICs, respectively, one may argue that our regression findings cover at least a critical part of the analysis. There may also be special aspects in the medical perspective that we as economists would want to cover only in a more interdisciplinary research context; international differences in health systems and hospital quality thus could play a role which is only indirectly covered here, namely in the number of infections registered in the various countries. With these caveats in mind, one may focus on preliminary policy conclusions.

There is a range of key policy conclusions one could draw as it was shown that the COVID-19 fatality rates of OECD countries depend on the number of coronavirus infected people, the share of overweight people in the population and the PM2.5 concentration (at a national level or in the respective biggest city; the latter variable is a proxy for air quality problems which have increased over decades in the major cities of OECD countries). As regards the air quality variable, further investigation is required in the future in order to clearly identify the relevance of air quality problems for infection dynamics and the fatality ratios in OECD countries and NICs, but one may also hope that more internationally comparative regional studies could be useful here.

As regards policy conclusions with respect to OECD countries and NICs, one may point out the following four key aspects:

- Leading OECD countries were rather strongly exposed to COVID-19 - at least as regards the fatality ratios. To the extent that strong trade, investment and tourism links with China have played a role in this aspect, effective epidemic policy in China is a prerequisite to restore international economic relations on a broad scale in a sustained manner. As regards cooperation between OECD countries and China in the field of health policy, the WHO still plays a crucial role - even as the US wants to leave the organization. The Trump 
Administration's economic and health policy has been rather contradictory over years (Welfens 2019).

- Countries which are heavily dependent on tourism in both Europe and Asia could play a crucial role in new outbreaks as international tourism is typically associated with often crowded locations in urban areas, such as restaurants, bars, discos etc. as well as beaches and other leisure areas. The nature of the pandemic makes it crucial that OECD countries and NICs should cooperate closely in both monitoring health conditions and in fighting the pandemic through effective and efficient measures.

- Some of the NICs are active in well-established regional economic integration groups - in Asia it is ASEAN, in Latin America Mercosur, and in Africa the ECOWAS. Such existing regional economic cooperation networks could also be useful networks in terms of effectively fighting the pandemic. Strong regional integration links make increased cooperation in health systems and epidemic policy a natural international policy perspective.

- The EU, with its strong trade links to all three aforementioned regional integration clubs, could launch a broader inter-regional cooperation initiative in pandemic policy cooperation which could influence the G20 policy agenda. In a period of little evident US international leadership, inter-regional networking could become a more important pillar of new joint leadership, but institution building in the respective integration clubs should be sufficiently strong - for example, an effective supranational institution in is missing in both ASEAN and ECOWAS. Transaction costs for inter-regional cooperation could be expected to be rather modest if institutional setups are rather similar as is the case if one compares Mercosur and the EU27. There is, of course, the caveat that nationalist-populist policy approaches, such as that in Brazil under President Jair Bolsonaro, can be a formidable obstacle for such enhanced inter-regional cooperation.

In the end, the UN - along with the WHO - will have to play a strong role in getting the pandemic under full control worldwide. The UN could also have a special challenge in helping to avoid uncontrolled new international migration waves in the Corona Recession which could lead to a new broad spreading of the coronavirus.

Some of the key empirical findings about OECD countries are also valid for the NICs and the whole sample of countries, respectively. There are also differences across the two country groups. The overall picture is that demographic, medical, economic and environmental variables play a significant role. Moreover, the epidemic herd immunity strategy cannot be recommended as the COVID-19 fatality ratio is raised by such a policy approach (only in the case that no vaccination would be developed within 2020 could that strategy make sense). To the extent that countries' governments do not want to implement a herd immunity strategy - allowing a controlled infection process and hoping that recovered infected patients become a critical barrier for spreading the virus - one would expect governments to implement anti-epidemic measures such as quarantine, social distancing and possibly lockdowns/shutdowns as an epidemic strategy while promoting R\&D on new vaccines. A large number of clinical tests for new vaccines is expected to bring new insights and possibly a 
vaccination in 2021 for broader strata of global society. In any case it remains crucial to understand the drivers of infections and COVID-19 fatality and empirical research should help to shed light on the relevant dynamics.

The medium term overlap of medical and economic problems could be different in OECD and NICS, respectively. As regards OECD countries, both the output decline in the first quarter of 2020 and the size of the negative output forecast of the IMF in the June 2020 outlook (IMF 2020b) was larger than for NICs which roughly are composed of medium income and low income countries as defined by the World Bank. Several OECD countries have witnessed an appreciation of the currency in the first quarter of 2020 as high capital inflows from NICs were recorded, although the capital flow reversals were lower than in the Transatlantic Banking Crisis 2008/09: While NICs faced a strong currency depreciation after the US banking crisis in autumn 2008, the foreign exchange markets have reacted more modestly to the Corona shock in the first half year of 2020 (Esteves and Sussman 2020). This could mean that a rather limited economic shock in the South plus the rather rapid stabilization of China in the first half of 2020 could help the OECD countries to get their economies restarted in 2021.

An important conclusion from the findings presented herein is that a strategy of achieving herd immunity early on is doubtful as it raises the number of infections as well as the fatality ratio in a significant way; in a broader perspective this approach is less convincing the faster a vaccination against the coronavirus becomes available. While it is true that selective policy interventions - summarized in the mean policy stringency variable - is not significant in the regressions presented, it seems too early to discard the usefulness of such policy interventions which include social distancing and quarantine measures. There is likely an indirect effect in the form of a reduced number of cases of infection and this aspect, as well as questions of regional variations, could only be analyzed in further research. As regards the environmental air quality variable, one should emphasize two points here: (i) This variable should be carefully considered in order to anticipate particular regional/national epidemic hotspots in a future second infection wave. (ii) An emphasis on sustainability policies which bring down particulate matter intensities should be understood to be also part of strategic health care policy.

It is interesting to recall the British Government's information on PM2.5, namely as noted by the British Department for Environment, Food \& Rural Affairs on its website (HM Government 2020): "Inhalation of particulate pollution can have adverse health impacts, and there is understood to be no safe threshold below which no adverse effects would be anticipated... The biggest impact of particulate air pollution on public health is understood to be from long-term exposure to PM2.5, which increases the agespecific mortality risk...". The government source continues to describe sources of PM2.5, in particular car traffic and industrial pollution, as well as heating processes; certain precursor gases are also relevant for the creation of PM2.5. In the future, assuming that our regression findings can be extended in a robust way for more UN countries - or a larger number of regions of the world economy - one would have to add the role of PM2.5 to an analysis of coronavirus pandemic fatality rates. One may expect that a switch from fossil fuels to renewable energy and climate change policy will considerably reduce PM2.5 air quality problems. According to the analysis 
presented herein, climate change policy would also reduce current and future fatality rates from COVID-19 and similar epidemics/pandemics so that there is an additional argument for promoting renewable energy and certain environmental innovations. The finding that obesity is a variable which is significantly raising case fatalities suggests that countries and regions, respectively, which have a relatively high indicator should prepare well for a second wave; and overlaps of regions showing high PM2.5 and high obesity indicators would suggest an "orange warning status". The red warning status would be for those regions/countries where there is an overlap of high PM2.5, high obesity figures and a high share of elderly people in the overall population.

Given the nature of a pandemic and the potential cross-border diffusion of epidemics, respectively, it is clear that every national policy response and health system reform in OECD countries - as well as in other countries (assuming similar findings as in OECD countries) - has elements of a multi-country/global international public good. The economic logic thus suggests that countries should join forces in part of epidemic prevention health care expenditures. Particular attention should be paid to sharing the costs of antiepidemic pharmaceutical and medical R\&D. The OECD countries should come up with a new approach and a special funding agency here where the OECD's outreach program e.g. including non-member countries such as India and China - could be a starting point to also include some other countries in a strategic multilateral approach.

One may emphasize that the rather homogenous country group of OECD countries should find it easier to create an international health policy cooperation club with joint funding for international public goods than the economically much more heterogenous G20 group. To the extent that one ultimately wants to realize a global public good at the UN level - including all countries of the world - a lead initiative of the OECD could still be useful in order to generate sufficient momentum to achieve the provision of a global public good in a rather fast two-stage approach. A direct UN approach might also have some advantages, but there is a risk that heterogenous interests and the high number of countries involved would in the end mean a delayed provision of the global public good compared to the two-stage approach - or a three-stage approach: OECDG20-UN (Welfens 2020b).

The fatality-increasing role of obesity points to a broad global need in the field of development policy not simply to push for an economic catching up of the global South which often goes along with a spreading of certain Western nutrition styles. Anti-obesity goals and an explicit emphasis on more sports activities for all generations as well enhanced company-based health and fitness programs should become a general element of catching-up policies. In the OECD countries themselves, policy initiatives for reducing obesity problems should follow a similar logic of better nutrition - such as encouraging the consumption of vegetables and fresh fruits as well as an emphasis, and more information, on low fat and low sugar products - and more sports. Institutionalized programs in schools, universities, the public administration and firms could be useful here, plus digital networking, which helps spreading relevant information and activities. The WHO has intensified its anti-obesity programs since 2018, but OECD countries have not been very active to include the relevant initiatives in its working programs: there is room for stronger WHO-OECD cooperation in this field and many OECD member countries, given high levels of obesity, have reason to become more active here.

Finally, the ageing of Western societies and of the population in Japan is a major long-term challenge for future epidemics. Beyond population policy and immigration 
incentives, little can be done in most OECD countries to slow the ageing process. However, there is an important policy implication with respect to membership contributions in certain international organizations. Given the international differential in terms of the ageing of populations of OECD countries (or UN member countries), one may argue that countries with a rather high ratio of the population aged 65 and over should contribute over-proportionately to the provision of international public goods in the field of prevention against and fighting of epidemics. So far in international organizations, the share of the elderly population plays no role in terms of the funding formula; the WHO could be the first organization where this aspect, emphasized in the research presented here, should have appropriate consequences. In a similar logic, one could argue that countries/regions with high PM2.5 indicators should also face higher contribution rates. The incentives from such modified contribution rates could clearly encourage welfare-enhancing political reforms and thus contribution formulas to international organizations could have a positive impact of global welfare in the long run. A broader analysis of UN countries is, however, required in a next empirical research step.

At the bottom line, it is clear that more research is needed, but the empirical findings presented could indeed be a useful starting point in the international economic and environmental coronavirus research. The broader research challenges in many ways will also require enhanced interdisciplinary research which would, of course, include the medical sciences on many topics. Both internationally comparative research, regional analysis, as well as spatial regression analysis for cities could be crucial see, for example, for New York (Chen et al. 2020); among the findings for New York, using spatial regression analysis, one may note that many contact-intensification points, including grocery shop density, green space density and median distance travelled plus, paradoxically, POIs of medicine density turned out to have a positive significant impact on infections. In a more international view, intensive contacts through travelling possibly related to trade, foreign investment or tourism - could be critical epidemic diffusion points which could indicate that the shadow price of economic globalization might be higher than traditionally considered. In a nutshell, the urban centers of globalization around the world could pay a higher price in a COVID-19 environment than less densely populated cities, regions and countries.

Here, and in the internationally comparative environmental quality dimensions, much future coronavirus research could be expected. As regards conclusions for policymakers, the suggested implications of our regression findings for dealing with a potential second wave of infections are already highly sensitive to being picked up quickly in the public debate worldwide.

The table below shows the number of lives which could have been saved had the spread of COVID-19 infections been delayed by 7 days and 14 days, respectively: Looking at the case of a 14-day delay, 37 countries would have saved more than 1,000 lives where the worst performers in absolute terms, namely India, the US and Indonesia, stand for approximately 60,000,14,000 and 12,000 deaths which could have been avoided, respectively; if one considers the case of a 7-day delay, there are still 25 countries which each could have saved a minimum of 1,000 lives each. For the three worst countries, the sum of lives saved would have been 42,814 (7-day delay) and 85,629 (14-day delay), for the 20 worst countries - coming both from OECD countries and NICs/LDCs - the sum would have been 83,460 (7-day delay) and 166,920 (14-day delay). The grand total for 104 countries would have been 108,185 (7-day delay) and 


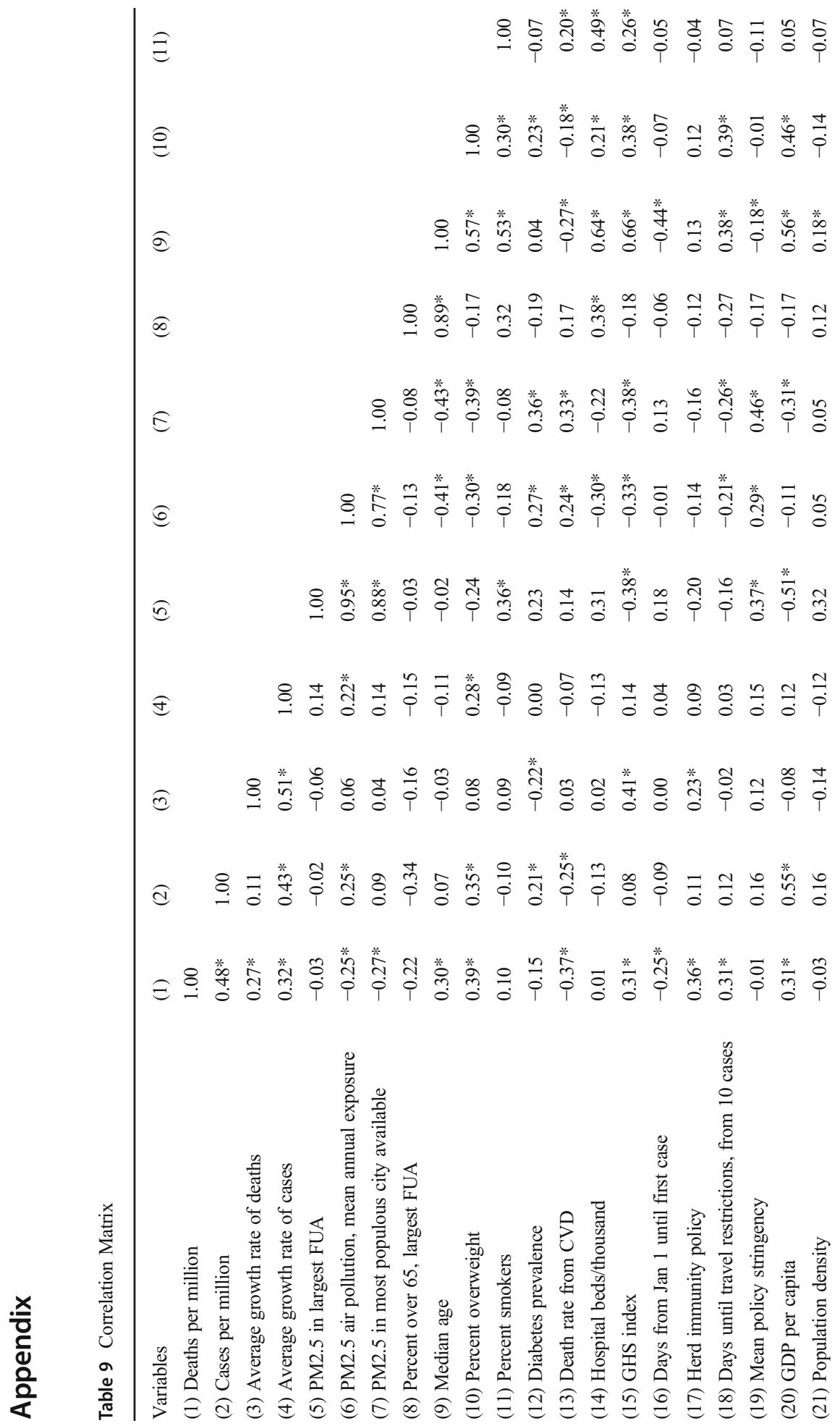




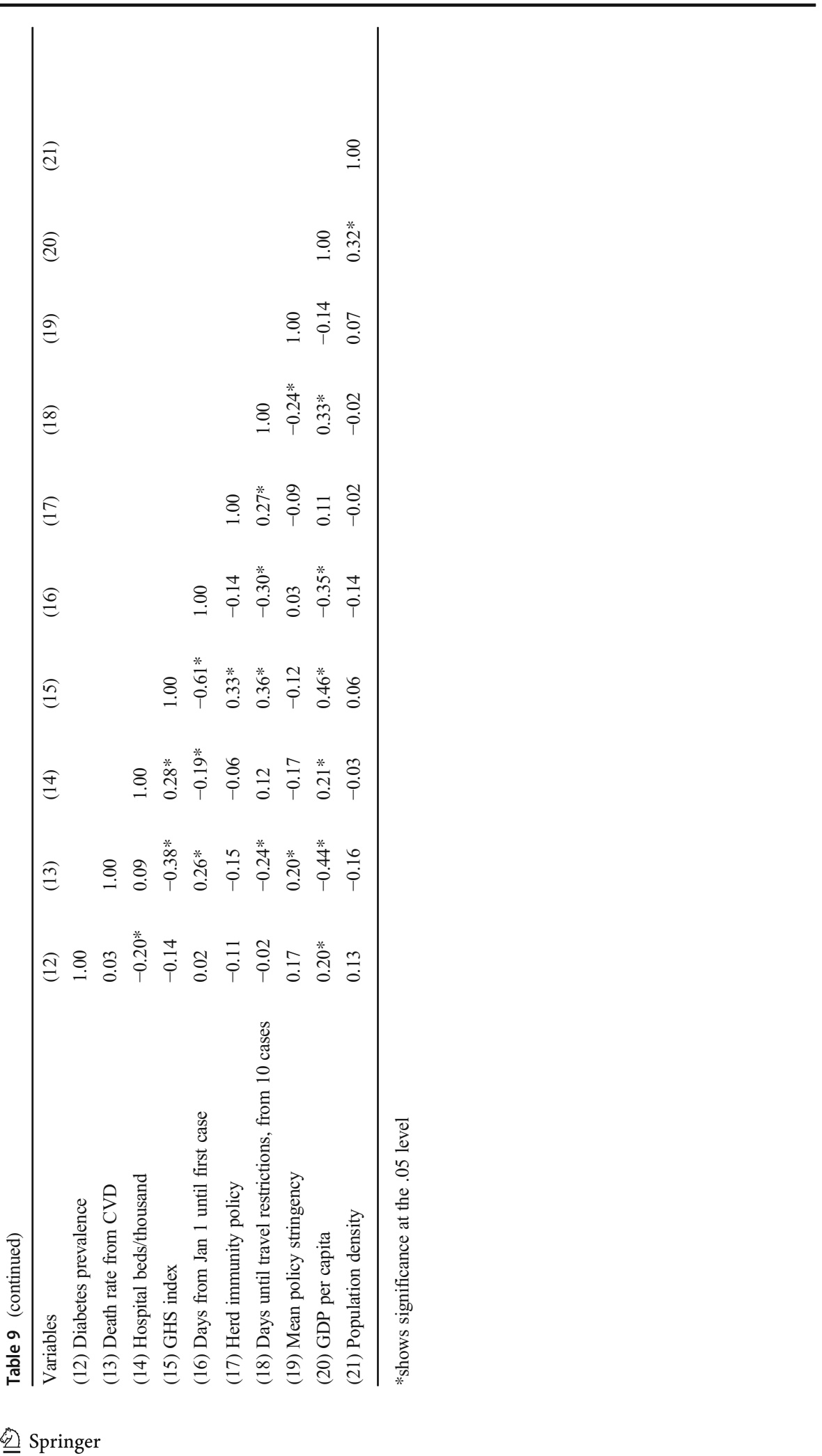


Table 10 Sample Selection

\begin{tabular}{|c|c|c|c|c|c|c|c|c|c|c|}
\hline Num & NAMES_STD & ISO3 & in_32 & in_37 & in_75 & in 77 & in_98 & in_104 & in_106 & in_108 \\
\hline 1 & Albania & ALB & No & No & Yes & Yes & Yes & Yes & Yes & Yes \\
\hline 2 & United Arab Emirates & ARE & No & No & No & Yes & Yes & Yes & Yes & Yes \\
\hline 3 & Argentina & ARG & No & No & No & Yes & Yes & Yes & Yes & Yes \\
\hline 4 & Australia & AUS & Yes & Yes & Yes & Yes & Yes & Yes & Yes & Yes \\
\hline 5 & Austria & AUT & Yes & Yes & Yes & Yes & Yes & Yes & Yes & Yes \\
\hline 6 & Azerbaijan & AZE & No & No & No & Yes & Yes & Yes & Yes & Yes \\
\hline 7 & Belgium & BEL & Yes & Yes & Yes & Yes & Yes & Yes & Yes & Yes \\
\hline 8 & Benin & $\mathrm{BEN}$ & No & No & No & No & Yes & Yes & Yes & Yes \\
\hline 9 & Bangladesh & BGD & No & No & Yes & No & Yes & Yes & Yes & Yes \\
\hline 10 & Bulgaria & BGR & No & No & Yes & Yes & Yes & Yes & Yes & Yes \\
\hline 11 & Bahrain & BHR & No & No & Yes & Yes & Yes & Yes & Yes & Yes \\
\hline 12 & Bosnia and Herzegovina & $\mathrm{BIH}$ & No & No & Yes & Yes & Yes & Yes & Yes & Yes \\
\hline 13 & Brazil & BRA & No & No & Yes & Yes & Yes & Yes & Yes & Yes \\
\hline 14 & Barbados & $\mathrm{BRB}$ & No & No & No & Yes & Yes & Yes & Yes & Yes \\
\hline 15 & Brunei Darussalam & $\mathrm{BRN}$ & No & No & No & Yes & Yes & Yes & Yes & Yes \\
\hline 16 & Botswana & BWA & No & No & No & Yes & Yes & Yes & Yes & Yes \\
\hline 17 & Canada & CAN & Yes & Yes & Yes & Yes & Yes & Yes & Yes & Yes \\
\hline 18 & Switzerland & CHE & Yes & Yes & Yes & Yes & Yes & Yes & Yes & Yes \\
\hline 19 & Chile & $\mathrm{CHL}$ & Yes & Yes & Yes & Yes & Yes & Yes & Yes & Yes \\
\hline 20 & China & $\mathrm{CHN}$ & No & No & No & No & No & No & No & Yes \\
\hline 21 & Colombia & $\mathrm{COL}$ & No & Yes & Yes & Yes & Yes & Yes & Yes & Yes \\
\hline 22 & Cabo Verde & $\mathrm{CPV}$ & No & No & No & No & Yes & Yes & Yes & Yes \\
\hline 23 & Costa Rica & CRI & No & No & Yes & Yes & Yes & Yes & Yes & Yes \\
\hline 24 & Cuba & CUB & No & No & Yes & Yes & Yes & Yes & No & Yes \\
\hline 25 & Cyprus & CYP & No & No & Yes & Yes & Yes & Yes & Yes & Yes \\
\hline 26 & Czech Republic & $\mathrm{CZE}$ & Yes & Yes & Yes & Yes & Yes & Yes & Yes & Yes \\
\hline 27 & Germany & DEU & Yes & Yes & Yes & Yes & Yes & Yes & Yes & Yes \\
\hline 28 & Djibouti & DJI & No & No & No & No & Yes & Yes & Yes & Yes \\
\hline 29 & Denmark & DNK & Yes & Yes & Yes & Yes & Yes & Yes & Yes & Yes \\
\hline 30 & Dominican Republic & DOM & No & No & No & Yes & Yes & Yes & Yes & Yes \\
\hline 31 & Algeria & DZA & No & No & No & No & Yes & Yes & Yes & Yes \\
\hline 32 & Ecuador & $\mathrm{ECU}$ & No & No & Yes & Yes & Yes & Yes & Yes & Yes \\
\hline 33 & Egypt, Arab Rep. & EGY & No & No & No & No & Yes & Yes & Yes & Yes \\
\hline 34 & Spain & ESP & Yes & Yes & Yes & Yes & Yes & Yes & Yes & Yes \\
\hline 35 & Estonia & EST & Yes & Yes & Yes & Yes & Yes & Yes & Yes & Yes \\
\hline 36 & Finland & FIN & Yes & Yes & Yes & Yes & Yes & Yes & Yes & Yes \\
\hline 37 & Fiji & FJI & No & No & Yes & Yes & No & Yes & Yes & Yes \\
\hline 38 & France & FRA & Yes & Yes & Yes & Yes & Yes & Yes & Yes & Yes \\
\hline 39 & United Kingdom & GBR & Yes & Yes & Yes & Yes & Yes & Yes & Yes & Yes \\
\hline 40 & Georgia & GEO & No & No & Yes & Yes & Yes & Yes & Yes & Yes \\
\hline 41 & Ghana & GHA & No & No & Yes & No & Yes & Yes & Yes & Yes \\
\hline
\end{tabular}


Table 10 (continued)

\begin{tabular}{|c|c|c|c|c|c|c|c|c|c|c|}
\hline Num & NAMES_STD & ISO3 & in_32 & in_37 & in_ 75 & in_ 77 & in_98 & in_104 & in_106 & in_108 \\
\hline 42 & Greece & GRC & Yes & Yes & Yes & Yes & Yes & Yes & Yes & Yes \\
\hline 43 & Croatia & HRV & No & No & Yes & Yes & Yes & Yes & Yes & Yes \\
\hline 44 & Hungary & HUN & Yes & Yes & Yes & Yes & Yes & Yes & Yes & Yes \\
\hline 45 & Indonesia & IDN & No & No & Yes & Yes & Yes & Yes & Yes & Yes \\
\hline 46 & India & IND & No & No & Yes & No & Yes & Yes & Yes & Yes \\
\hline 47 & Ireland & IRL & Yes & Yes & Yes & Yes & Yes & Yes & Yes & Yes \\
\hline 48 & Iran, Islamic Rep. & IRN & No & No & Yes & Yes & Yes & Yes & Yes & Yes \\
\hline 49 & Iceland & ISL & No & Yes & Yes & Yes & Yes & Yes & Yes & Yes \\
\hline 50 & Israel & ISR & No & Yes & Yes & Yes & Yes & Yes & Yes & Yes \\
\hline 51 & Italy & ITA & Yes & Yes & Yes & Yes & Yes & Yes & Yes & Yes \\
\hline 52 & Jamaica & JAM & No & No & No & Yes & Yes & Yes & Yes & Yes \\
\hline 53 & Japan & JPN & Yes & Yes & Yes & Yes & Yes & Yes & Yes & Yes \\
\hline 54 & Kazakhstan & KAZ & No & No & No & Yes & Yes & Yes & Yes & Yes \\
\hline 55 & Kenya & KEN & No & No & Yes & No & Yes & Yes & Yes & Yes \\
\hline 56 & Kyrgyz Republic & KGZ & No & No & No & No & Yes & Yes & Yes & Yes \\
\hline 57 & Cambodia & KHM & No & No & No & No & No & Yes & Yes & Yes \\
\hline 58 & Korea, Rep. & KOR & Yes & Yes & Yes & Yes & Yes & Yes & Yes & Yes \\
\hline 59 & Kuwait & KWT & No & No & Yes & Yes & Yes & Yes & Yes & Yes \\
\hline 60 & Lao PDR & LAO & No & No & No & No & No & Yes & Yes & Yes \\
\hline 61 & Sri Lanka & LKA & No & No & No & No & Yes & Yes & Yes & Yes \\
\hline 62 & Lesotho & LSO & No & No & No & No & No & No & Yes & Yes \\
\hline 63 & Lithuania & LTU & Yes & Yes & Yes & Yes & Yes & Yes & Yes & Yes \\
\hline 64 & Luxembourg & LUX & Yes & Yes & Yes & Yes & Yes & Yes & Yes & Yes \\
\hline 65 & Latvia & LVA & Yes & Yes & Yes & Yes & Yes & Yes & Yes & Yes \\
\hline 66 & Morocco & MAR & No & No & Yes & No & Yes & Yes & Yes & Yes \\
\hline 67 & Moldova & MDA & No & No & No & No & Yes & Yes & Yes & Yes \\
\hline 68 & Mexico & MEX & Yes & Yes & Yes & Yes & Yes & Yes & Yes & Yes \\
\hline 69 & Mongolia & MNG & No & No & Yes & No & No & Yes & Yes & Yes \\
\hline 70 & Mauritius & MUS & No & No & No & Yes & Yes & Yes & Yes & Yes \\
\hline 71 & Malaysia & MYS & No & No & No & Yes & Yes & Yes & Yes & Yes \\
\hline 72 & Namibia & NAM & No & No & No & No & No & No & Yes & Yes \\
\hline 73 & Netherlands & NLD & Yes & Yes & Yes & Yes & Yes & Yes & Yes & Yes \\
\hline 74 & Norway & NOR & Yes & Yes & Yes & Yes & Yes & Yes & Yes & Yes \\
\hline 75 & Nepal & NPL & No & No & Yes & No & Yes & Yes & Yes & Yes \\
\hline 76 & New Zealand & NZL & No & Yes & Yes & Yes & Yes & Yes & Yes & Yes \\
\hline 77 & Oman & $\mathrm{OMN}$ & No & No & No & Yes & Yes & Yes & Yes & Yes \\
\hline 78 & Pakistan & PAK & No & No & Yes & No & Yes & Yes & Yes & Yes \\
\hline 79 & Panama & PAN & No & No & Yes & Yes & Yes & Yes & Yes & Yes \\
\hline 80 & Philippines & PHL & No & No & Yes & No & Yes & Yes & Yes & Yes \\
\hline 81 & Poland & POL & Yes & Yes & Yes & Yes & Yes & Yes & Yes & Yes \\
\hline 82 & Portugal & PRT & Yes & Yes & Yes & Yes & Yes & Yes & Yes & Yes \\
\hline 83 & Paraguay & PRY & No & No & Yes & Yes & Yes & Yes & Yes & Yes \\
\hline
\end{tabular}


Table 10 (continued)

\begin{tabular}{|c|c|c|c|c|c|c|c|c|c|c|}
\hline Num & NAMES_STD & ISO3 & in_32 & in_37 & in_75 & in_ 77 & in_98 & in_104 & in_106 & in_108 \\
\hline 84 & Qatar & QAT & No & No & No & Yes & Yes & Yes & Yes & Yes \\
\hline 85 & Romania & ROU & No & No & Yes & Yes & Yes & Yes & Yes & Yes \\
\hline 86 & Russian Federation & RUS & No & No & Yes & Yes & Yes & Yes & Yes & Yes \\
\hline 87 & Saudi Arabia & SAU & No & No & Yes & Yes & Yes & Yes & Yes & Yes \\
\hline 88 & Senegal & SEN & No & No & No & No & No & No & Yes & Yes \\
\hline 89 & Singapore & SGP & No & No & Yes & Yes & Yes & Yes & Yes & Yes \\
\hline 90 & El Salvador & SLV & No & No & Yes & No & Yes & Yes & Yes & Yes \\
\hline 91 & Serbia & SRB & No & No & Yes & Yes & Yes & Yes & Yes & Yes \\
\hline 92 & Suriname & SUR & No & No & No & Yes & Yes & Yes & Yes & Yes \\
\hline 93 & Slovak Republic & SVK & Yes & Yes & Yes & Yes & Yes & Yes & Yes & Yes \\
\hline 94 & Slovenia & SVN & Yes & Yes & Yes & Yes & Yes & Yes & Yes & Yes \\
\hline 95 & Sweden & SWE & Yes & Yes & Yes & Yes & Yes & Yes & Yes & Yes \\
\hline 96 & Eswatini & SWZ & No & No & No & No & Yes & Yes & Yes & Yes \\
\hline 97 & Seychelles & SYC & No & No & No & Yes & No & Yes & Yes & Yes \\
\hline 98 & Thailand & THA & No & No & Yes & Yes & Yes & Yes & Yes & Yes \\
\hline 99 & Tunisia & TUN & No & No & No & No & Yes & Yes & Yes & Yes \\
\hline 100 & Turkey & TUR & No & Yes & Yes & Yes & Yes & Yes & Yes & Yes \\
\hline 101 & Tanzania & TZA & No & No & Yes & No & Yes & Yes & Yes & Yes \\
\hline 102 & Ukraine & UKR & No & No & Yes & No & Yes & Yes & Yes & Yes \\
\hline 103 & Uruguay & URY & No & No & Yes & Yes & Yes & Yes & Yes & Yes \\
\hline 104 & United States & USA & Yes & Yes & Yes & Yes & Yes & Yes & Yes & Yes \\
\hline 105 & Uzbekistan & UZB & No & No & No & No & Yes & Yes & Yes & Yes \\
\hline 106 & Vietnam & VNM & No & No & Yes & No & No & Yes & Yes & Yes \\
\hline 107 & South Africa & $\mathrm{ZAF}$ & No & No & Yes & Yes & Yes & Yes & Yes & Yes \\
\hline 108 & Zambia & ZMB & No & No & No & No & Yes & Yes & Yes & Yes \\
\hline
\end{tabular}


Table 11 Robustness check, Full sample, COVID-19 Deaths

\begin{tabular}{|c|c|c|c|c|c|}
\hline \multirow{3}{*}{ Variables } & (1) & (2) & (3) & (4) & (5) \\
\hline & $\begin{array}{l}\text { Deaths per } \\
\text { million }\end{array}$ & $\begin{array}{l}\text { Deaths per } \\
\text { million }\end{array}$ & $\begin{array}{l}\text { Deaths per } \\
\text { million }\end{array}$ & $\begin{array}{l}\text { Deaths per } \\
\text { million }\end{array}$ & $\begin{array}{l}\text { Avg. growth } \\
\text { rate, deaths }\end{array}$ \\
\hline & full sample & full sample & full sample & $\begin{array}{l}\text { U. middle \& } \\
\text { High income }\end{array}$ & full sample \\
\hline \multirow{2}{*}{$\begin{array}{l}\text { PM2.5 air pollution, mean } \\
\text { annual exposure }\end{array}$} & -0.817 & -0.951 & & -1.824 & $0.022 *$ \\
\hline & $(0.865)$ & $(0.780)$ & & $(1.759)$ & $(0.013)$ \\
\hline \multirow{2}{*}{$\begin{array}{l}\text { PM2.5 in most populous city } \\
\text { available }\end{array}$} & & & 0.586 & & \\
\hline & & & $(0.878)$ & & \\
\hline \multirow[t]{2}{*}{ Cases per million } & $0.010 * *$ & $0.008 * *$ & $0.014^{* * * *}$ & $0.009 * *$ & \\
\hline & $(0.005)$ & $(0.004)$ & $(0.004)$ & $(0.004)$ & \\
\hline \multirow[t]{2}{*}{ Median age } & -2.497 & $-6.288 * *$ & $-8.914 * *$ & $-6.320 *$ & $-0.163^{* * *}$ \\
\hline & $(2.713)$ & $(2.801)$ & $(3.972)$ & $(3.409)$ & $(0.059)$ \\
\hline \multirow[t]{2}{*}{ Percent overweight } & 1.148 & 1.905 & $4.509^{*}$ & 3.266 & 0.011 \\
\hline & (1.111) & $(1.415)$ & $(2.403)$ & $(2.312)$ & $(0.029)$ \\
\hline \multirow[t]{2}{*}{ Percent smokers } & 0.041 & 1.608 & 1.265 & 1.757 & 0.053 \\
\hline & $(1.806)$ & $(1.695)$ & $(2.220)$ & $(2.532)$ & $(0.035)$ \\
\hline \multirow[t]{2}{*}{ Death rate from CVD } & $-0.373^{* * *} *$ & $-0.211^{*}$ & -0.152 & $-0.393 * *$ & -0.00004 \\
\hline & $(0.132)$ & $(0.124)$ & $(0.162)$ & $(0.178)$ & $(0.002)$ \\
\hline \multirow[t]{2}{*}{ Diabetes prevalence } & -5.964 & -2.508 & -7.708 & 1.480 & -0.056 \\
\hline & $(3.722)$ & $(3.472)$ & $(7.549)$ & $(4.226)$ & $(0.055)$ \\
\hline \multirow[t]{2}{*}{ GHS index } & & 0.345 & 0.933 & -0.774 & $0.084 * * *$ \\
\hline & & $(1.569)$ & $(2.479)$ & $(2.442)$ & $(0.027)$ \\
\hline \multirow[t]{2}{*}{ Herd immunity policy } & & $237.469 * * *$ & $186.228 * * *$ & $244.461 * * *$ & $1.672 *$ \\
\hline & & $(54.260)$ & $(58.452)$ & $(57.459)$ & $(0.957)$ \\
\hline \multirow{2}{*}{$\begin{array}{l}\text { Days until travel restrictions, } \\
\text { from } 10 \text { cases }\end{array}$} & & 0.505 & 0.530 & & \\
\hline & & $(0.372)$ & $(0.520)$ & & \\
\hline \multirow{2}{*}{$\begin{array}{l}\text { Days from Jan } 1 \text { until first } \\
\text { case }\end{array}$} & & $-2.911 * *$ & $-4.486^{* *}$ & $-4.797 * *$ & $-0.036^{* *}$ \\
\hline & & $(1.357)$ & $(2.035)$ & $(2.014)$ & $(0.017)$ \\
\hline \multirow[t]{2}{*}{ Constant } & $191.999 *$ & $304.602 *$ & 303.668 & 365.840 & $5.040 *$ \\
\hline & $(100.302)$ & $(159.503)$ & $(226.017)$ & $(255.648)$ & $(2.788)$ \\
\hline Observations & 108 & 106 & 76 & 78 & 100 \\
\hline R-squared & 0.397 & 0.572 & 0.624 & 0.583 & 0.413 \\
\hline Region dummies & YES & YES & YES & YES & YES \\
\hline
\end{tabular}

Robust standard errors in parentheses

$* * * \mathrm{p}<0.01, * * \mathrm{p}<0.05, * \mathrm{p}<0.1$ 
Table 12 Robustness check, Full sample, COVID-19 Cases

\begin{tabular}{|c|c|c|c|c|c|}
\hline \multirow{3}{*}{ Variables } & (1) & (2) & (3) & (4) & $(5)$ \\
\hline & $\begin{array}{l}\text { Cases per } \\
\text { million }\end{array}$ & $\begin{array}{l}\text { Cases per } \\
\text { million }\end{array}$ & $\begin{array}{l}\text { Cases per } \\
\text { million }\end{array}$ & Cases per million & $\begin{array}{l}\text { Avg. growth } \\
\text { rate, cases }\end{array}$ \\
\hline & full sample & full sample & full sample & $\begin{array}{l}\text { U. middle \& High } \\
\text { income }\end{array}$ & full sample \\
\hline \multirow{2}{*}{$\begin{array}{l}\text { PM2.5 air pollution, mean } \\
\text { annual exposure }\end{array}$} & $82.237^{*}$ & $82.532 *$ & & $153.784 *$ & $0.041 * *$ \\
\hline & $(45.554)$ & $(47.970)$ & & $(85.986)$ & $(0.018)$ \\
\hline \multirow{2}{*}{$\begin{array}{l}\text { PM2.5 in most populous city } \\
\text { available }\end{array}$} & & & $42.716^{* *}$ & & \\
\hline & & & $(16.972)$ & & \\
\hline \multirow[t]{2}{*}{ Median age } & $-135.163 * *$ & $-125.666^{*}$ & -93.550 & -152.123 & $-0.118^{*}$ \\
\hline & $(63.048)$ & (74.144) & $(80.861)$ & $(95.558)$ & $(0.065)$ \\
\hline \multirow[t]{2}{*}{ Percent overweight } & -15.582 & -17.510 & 37.518 & 35.932 & 0.021 \\
\hline & $(31.844)$ & $(38.779)$ & (26.623) & $(45.396)$ & $(0.030)$ \\
\hline \multirow[t]{2}{*}{ Percent smokers } & 53.914 & 60.324 & 158.671 & 96.815 & -0.008 \\
\hline & $(73.994)$ & $(79.847)$ & $(96.707)$ & $(106.404)$ & $(0.031)$ \\
\hline \multirow[t]{2}{*}{ Death rate from CVD } & 0.538 & -0.498 & -2.682 & -0.715 & -0.001 \\
\hline & (4.698) & (4.849) & (4.974) & (6.496) & $(0.003)$ \\
\hline \multirow[t]{2}{*}{ Diabetes prevalence } & 10.242 & -10.516 & $323.789 *$ & -91.113 & -0.004 \\
\hline & $(107.408)$ & $(104.436)$ & $(161.754)$ & $(142.934)$ & $(0.065)$ \\
\hline \multirow[t]{2}{*}{ GHS index } & 24.107 & 4.411 & -45.980 & -1.777 & $0.055^{*}$ \\
\hline & $(45.340)$ & $(46.341)$ & $(51.891)$ & $(55.485)$ & $(0.029)$ \\
\hline \multirow[t]{2}{*}{ GDP per capita } & $0.158 * * *$ & $0.158 * * *$ & $0.120 * * *$ & $0.144 * * *$ & 0.00002 \\
\hline & $(0.050)$ & $(0.057)$ & $(0.030)$ & $(0.050)$ & $(0.000)$ \\
\hline \multirow[t]{2}{*}{ Population density } & & 0.155 & 0.290 & 0.256 & 0.00004 \\
\hline & & $(0.611)$ & $(0.424)$ & $(0.468)$ & $(0.000)$ \\
\hline \multirow[t]{2}{*}{ Herd immunity policy } & & $3397.35^{*}$ & $3851.24 * *$ & $3676.91 *$ & -0.08 \\
\hline & & (1930.06) & $(1525.08)$ & $(1852.67)$ & $(1.04)$ \\
\hline \multirow{2}{*}{$\begin{array}{l}\text { Days until travel restrictions, } \\
\text { from } 10 \text { cases }\end{array}$} & & $-23.760 *$ & -10.142 & -19.548 & -0.004 \\
\hline & & $(12.685)$ & $(11.233)$ & $(12.224)$ & $(0.007)$ \\
\hline \multirow{2}{*}{$\begin{array}{l}\text { Days from Jan } 1 \text { until first } \\
\text { case }\end{array}$} & & -10.913 & $-68.604 * * *$ & -35.085 & 0.007 \\
\hline & & $(27.827)$ & $(22.915)$ & $(37.411)$ & $(0.020)$ \\
\hline \multirow[t]{2}{*}{ Constant } & -2753.39 & -1801.01 & -2511.10 & -2843.47 & 4.71 \\
\hline & $(4369.65)$ & $(4549.43)$ & $(5746.17)$ & $(7834.86)$ & $(3.04)$ \\
\hline Observations & 106 & 105 & 75 & 77 & 105 \\
\hline R-squared & 0.572 & 0.599 & 0.654 & 0.683 & 0.411 \\
\hline Region dummies & YES & YES & YES & $\mathrm{NO}$ & YES \\
\hline
\end{tabular}

Robust standard errors in parentheses

$* * * \mathrm{p}<0.01, * * \mathrm{p}<0.05, * \mathrm{p}<0.1$ 
Table 13 Lives Saved by Postponing COVID-19 Infections by 7 Days/14 Days (based on Tab. 7). The table below shows the number of lives which could have been saved had the spread of COVID-19 infections been delayed by 7 days and 14 days, respectively: Looking at the case of a 14-day delay, 37 countries would have saved more than 1000 lives where the worst performers in absolute terms, namely India, the US and Indonesia, stand for approximately 60,000,14,000 and 12,000 deaths which could have been avoided, respectively; if one considers the case of a 7-day delay, there are still 25 countries which each could have saved a minimum of 1000 lives each. For the three worst countries, the sum of lives saved would have been 42,814 (7-day delay) and 85,629 (14-day delay), for the 20 worst countries - coming both from OECD countries and NICs/LDCs the sum would have been 83,460 (7-day delay) and 166,920 (14-day delay). The grand total for 104 countries would have been 108,185 (7-day delay) and 216,369 (14-day delay), respectively. The 7-day delay figure is a hypothetical implicit finding based on the present study and in most industrialized countries the number of lives saved from postponing the first infections by one week indeed makes sense (e.g., $5 \%$ in the US; $5 \%$ in France, $4 \%$ in Italy and Spain, 9\% in Canada - based on total COVID-19 fatalities recorded as of July 20, 2020). In countries with very low number of fatalities officially recorded - often obviously standing for underreporting in many developing countries - or in economies where the peak of the infection is still several months away, the implicit figure for lives saved as a result of a 7-day delay could exceed the actual number of fatalities by the reference date of July 20 . However, the approach itself remains a useful analytical exercise and by the end of 2020 more countries with meaningful (post-peak) results should be also be recorded in the socalled South of the world economy. Lower fatality rates typically mean less problems for the relevant health care system and certainly also welfare gains; in terms of the economic effects, a lower fatality figure could not only mean higher effective employment figures in the medium term and long run but also less of a negative psychological "scarring effect" in the population which undermines consumption demand. Countries with a relatively early and focused epidemic policy have thus recorded considerable gains by saving lives. Countries with greatly reduced fatality figures (in the case of delaying infections) from the same region would have benefitted jointly from a lower reduction of trade, foreign investment and output if one follows the logic of the gravity equation for trade and foreign direct investment.

\begin{tabular}{|c|c|c|c|c|c|c|}
\hline No. & ISO3 & Economies & a) Population & $\begin{array}{l}\text { b) } 7 \text { days delay } \\
\text { figure }\end{array}$ & $\begin{array}{l}\text { c) } 14 \text { days delay } \\
\text { figure }\end{array}$ & $\begin{array}{l}\text { d) COVID-19 Total } \\
\text { deaths until } \\
\text { 20th July } 2020\end{array}$ \\
\hline 1 & IND & India & $1,380,004,385$ & $29,772.21$ & $59,544.43$ & 27,497 \\
\hline 2 & USA & United States & $331,002,647$ & 7141.05 & $14,282.10$ & 140,534 \\
\hline 3 & IDN & Indonesia & $273,523,621$ & 5901.00 & $11,802.00$ & 4143 \\
\hline 4 & PAK & Pakistan & $220,892,331$ & 4765.53 & 9531.06 & 5599 \\
\hline 5 & BRA & Brazil & $212,559,409$ & 4585.76 & 9171.51 & 79,488 \\
\hline 6 & BGD & Bangladesh & $164,689,383$ & 3553.01 & 7106.02 & 2618 \\
\hline 7 & RUS & $\begin{array}{l}\text { Russian } \\
\text { Federation }\end{array}$ & $145,934,460$ & 3148.39 & 6296.78 & 12,342 \\
\hline 8 & MEX & Mexico & $128,932,753$ & 2781.60 & 5563.19 & 39,184 \\
\hline 9 & JPN & Japan & $126,476,458$ & 2728.60 & 5457.21 & 985 \\
\hline 10 & PHL & Philippines & $109,581,085$ & 2364.10 & 4728.20 & 1831 \\
\hline 11 & EGY & Egypt, Arab Rep. & $102,334,403$ & 2207.76 & 4415.52 & 4302 \\
\hline 12 & VNM & Vietnam & $97,338,583$ & 2099.98 & 4199.97 & 0 \\
\hline 13 & TUR & Turkey & $84,339,067$ & 1819.53 & 3639.06 & 5491 \\
\hline 14 & IRN & Iran, Islamic Rep. & $83,992,953$ & 1812.06 & 3624.13 & 14,188 \\
\hline 15 & DEU & Germany & $83,783,945$ & 1807.55 & 3615.11 & 9086 \\
\hline 16 & THA & Thailand & $69,799,978$ & 1505.86 & 3011.73 & 58 \\
\hline 17 & GBR & United Kingdom & $67,886,004$ & 1464.57 & 2929.15 & 45,300 \\
\hline 18 & FRA & France & $65,273,512$ & 1408.21 & 2816.42 & 30,152 \\
\hline 19 & ITA & Italy & $60,461,828$ & 1304.40 & 2608.81 & 35,045 \\
\hline 20 & TZA & Tanzania & $59,734,213$ & 1288.71 & 2577.41 & 21 \\
\hline
\end{tabular}


Table 13 (continued)

\begin{tabular}{|c|c|c|c|c|c|c|}
\hline No. & ISO3 & Economies & a) Population & $\begin{array}{l}\text { b) } 7 \text { days delay } \\
\text { figure }\end{array}$ & $\begin{array}{l}\text { c) } 14 \text { days delay } \\
\text { figure }\end{array}$ & $\begin{array}{l}\text { d) COVID-19 Total } \\
\text { deaths until } \\
\text { 20th July } 2020\end{array}$ \\
\hline 21 & $\mathrm{ZAF}$ & South Africa & $59,308,690$ & 1279.53 & 2559.05 & 5033 \\
\hline 22 & KEN & Kenya & $53,771,300$ & 1160.06 & 2320.12 & 234 \\
\hline 23 & KOR & Korea, Rep. & $51,269,183$ & 1106.08 & 2212.16 & 296 \\
\hline 24 & $\mathrm{COL}$ & Colombia & $50,882,884$ & 1097.75 & 2195.49 & 6736 \\
\hline 25 & ESP & Spain & $46,754,783$ & 1008.69 & 2017.38 & 28,422 \\
\hline 26 & $\mathrm{ARG}$ & Argentina & $45,195,777$ & 975.05 & 1950.11 & 2246 \\
\hline 27 & DZA & Algeria & $43,851,043$ & 946.04 & 1892.08 & 1078 \\
\hline 28 & UKR & Ukraine & $43,733,759$ & 943.51 & 1887.02 & 1485 \\
\hline 29 & POL & Poland & $37,846,605$ & 816.50 & 1633.01 & 1624 \\
\hline 30 & $\mathrm{CAN}$ & Canada & $37,742,157$ & 814.25 & 1628.50 & 8852 \\
\hline 31 & MAR & Morocco & $36,910,558$ & 796.31 & 1592.62 & 273 \\
\hline 32 & SAU & Saudi Arabia & $34,813,867$ & 751.07 & 1502.15 & 2486 \\
\hline 33 & UZB & Uzbekistan & $33,469,199$ & 722.06 & 1444.13 & 88 \\
\hline 34 & MYS & Malaysia & $32,365,998$ & 698.26 & 1396.53 & 123 \\
\hline 35 & GHA & Ghana & $31,072,945$ & 670.37 & 1340.74 & 148 \\
\hline 36 & NPL & Nepal & $29,136,808$ & 628.60 & 1257.19 & 40 \\
\hline 37 & AUS & Australia & $25,499,881$ & 550.13 & 1100.27 & 122 \\
\hline 38 & LKA & Sri Lanka & $21,413,250$ & 461.97 & 923.94 & 11 \\
\hline 39 & ROU & Romania & $19,237,682$ & 415.03 & 830.07 & 2026 \\
\hline 40 & CHL & Chile & $19,116,209$ & 412.41 & 824.83 & 8503 \\
\hline 41 & KAZ & Kazakhstan & $18,776,707$ & 405.09 & 810.18 & 375 \\
\hline 42 & $\mathrm{ZMB}$ & Zambia & $18,383,956$ & 396.62 & 793.23 & 109 \\
\hline 43 & $\mathrm{ECU}$ & Ecuador & $17,643,060$ & 380.63 & 761.26 & 5313 \\
\hline 44 & NLD & Netherlands & $17,134,873$ & 369.67 & 739.34 & 6136 \\
\hline 45 & KHM & Cambodia & $16,718,971$ & 360.70 & 721.39 & 0 \\
\hline 46 & BEN & Benin & $12,123,198$ & 261.55 & 523.09 & 31 \\
\hline 47 & TUN & Tunisia & $11,818,618$ & 254.97 & 509.95 & 50 \\
\hline 48 & BEL & Belgium & $11,589,616$ & 250.03 & 500.07 & 9800 \\
\hline 49 & CUB & Cuba & $11,326,616$ & 244.36 & 488.72 & 87 \\
\hline 50 & DOM & $\begin{array}{l}\text { Dominican } \\
\text { Republic }\end{array}$ & $10,847,904$ & 234.03 & 468.07 & 981 \\
\hline 51 & CZE & Czech Republic & $10,708,982$ & 231.04 & 462.07 & 359 \\
\hline 52 & GRC & Greece & $10,423,056$ & 224.87 & 449.73 & 194 \\
\hline 53 & PRT & Portugal & $10,196,707$ & 219.98 & 439.97 & 1689 \\
\hline 54 & AZE & Azerbaijan & $10,139,175$ & 218.74 & 437.49 & 354 \\
\hline 55 & SWE & Sweden & $10,099,270$ & 217.88 & 435.76 & 5619 \\
\hline 56 & ARE & $\begin{array}{c}\text { United Arab } \\
\text { Emirates }\end{array}$ & $9,890,400$ & 213.38 & 426.75 & 339 \\
\hline 57 & HUN & Hungary & $9,660,350$ & 208.41 & 416.82 & 596 \\
\hline 58 & AUT & Austria & $9,006,400$ & 194.30 & 388.61 & 711 \\
\hline 59 & ISR & Israel & $8,655,541$ & 186.73 & 373.47 & 409 \\
\hline
\end{tabular}


Table 13 (continued)

No. ISO3 Economies

a) Population b) 7 days delay c) 14 days delay d) COVID-19 Total figure figure deaths until 20th July 2020

\begin{tabular}{|c|c|c|c|c|c|c|}
\hline 60 & $\mathrm{CHE}$ & Switzerland & $8,654,618$ & 186.71 & 373.43 & 1687 \\
\hline 61 & LAO & Lao PDR & $7,275,556$ & 156.96 & 313.93 & 0 \\
\hline 62 & PRY & Paraguay & $7,132,530$ & 153.88 & 307.75 & 31 \\
\hline 63 & BGR & Bulgaria & $6,948,445$ & 149.91 & 299.81 & 300 \\
\hline 64 & $\mathrm{SRB}$ & Serbia & $6,804,596$ & 146.80 & 293.60 & 472 \\
\hline 65 & KGZ & Kyrgyz Republic & $6,524,191$ & 140.75 & 281.51 & 1037 \\
\hline 66 & SLV & El Salvador & $6,486,201$ & 139.93 & 279.87 & 344 \\
\hline 67 & SGP & Singapore & $5,850,343$ & 126.22 & 252.43 & 27 \\
\hline 68 & DNK & Denmark & $5,792,203$ & 124.96 & 249.92 & 611 \\
\hline 69 & FIN & Finland & $5,540,718$ & 119.54 & 239.07 & 328 \\
\hline 70 & SVK & Slovak Republic & $5,459,643$ & 117.79 & 235.57 & 28 \\
\hline 71 & NOR & Norway & $5,421,242$ & 116.96 & 233.92 & 255 \\
\hline 72 & $\mathrm{OMN}$ & Oman & $5,106,622$ & 110.17 & 220.34 & 318 \\
\hline 73 & CRI & Costa Rica & $5,094,114$ & 109.90 & 219.80 & 62 \\
\hline 74 & IRL & Ireland & $4,937,796$ & 106.53 & 213.06 & 1753 \\
\hline 75 & NZL & New Zealand & $4,822,233$ & 104.03 & 208.07 & 22 \\
\hline 76 & PAN & Panama & $4,314,768$ & 93.09 & 186.17 & 1096 \\
\hline 77 & KWT & Kuwait & $4,270,563$ & 92.13 & 184.27 & 408 \\
\hline 78 & HRV & Croatia & $4,105,268$ & 88.57 & 177.13 & 120 \\
\hline 79 & MDA & Moldova & $4,033,963$ & 87.03 & 174.06 & 684 \\
\hline 80 & GEO & Georgia & $3,989,175$ & 86.06 & 172.12 & 15 \\
\hline 81 & URY & Uruguay & $3,473,727$ & 74.94 & 149.88 & 33 \\
\hline 82 & $\mathrm{BIH}$ & $\begin{array}{l}\text { Bosnia and } \\
\text { Herzegovina }\end{array}$ & $3,280,815$ & 70.78 & 141.56 & 245 \\
\hline 83 & MNG & Mongolia & $3,278,292$ & 70.73 & 141.45 & 0 \\
\hline 84 & JAM & Jamaica & $2,961,161$ & 63.88 & 127.77 & 10 \\
\hline 85 & QAT & Qatar & $2,881,060$ & 62.16 & 124.31 & 157 \\
\hline 86 & ALB & Albania & $2,877,800$ & 62.09 & 124.17 & 112 \\
\hline 87 & LTU & Lithuania & $2,722,291$ & 58.73 & 117.46 & 80 \\
\hline 88 & BWA & Botswana & $2,351,625$ & 50.73 & 101.47 & 1 \\
\hline 89 & SVN & Slovenia & $2,078,932$ & 44.85 & 89.70 & 111 \\
\hline 90 & LVA & Latvia & $1,886,202$ & 40.69 & 81.39 & 31 \\
\hline 91 & BHR & Bahrain & $1,701,583$ & 36.71 & 73.42 & 126 \\
\hline 92 & EST & Estonia & $1,326,539$ & 28.62 & 57.24 & 69 \\
\hline 93 & MUS & Mauritius & $1,271,767$ & 27.44 & 54.87 & 10 \\
\hline 94 & SWZ & Eswatini & 1160,164 & 25.03 & 50.06 & 21 \\
\hline 95 & DJI & Djibouti & 988,002 & 21.32 & 42.63 & 56 \\
\hline 96 & FJI & Fiji & 896,444 & 19.34 & 38.68 & 0 \\
\hline 97 & CYP & Cyprus & 875,899 & 18.90 & 37.79 & 19 \\
\hline 98 & LUX & Luxembourg & 625,976 & 13.50 & 27.01 & 111 \\
\hline 99 & SUR & Suriname & 586,634 & 12.66 & 25.31 & 21 \\
\hline
\end{tabular}


Table 13 (continued)

\begin{tabular}{|c|c|c|c|c|c|c|}
\hline No. & ISO3 & Economies & a) Population & $\begin{array}{l}\text { b) } 7 \text { days delay } \\
\text { figure }\end{array}$ & $\begin{array}{l}\text { c) } 14 \text { days delay } \\
\text { figure }\end{array}$ & $\begin{array}{l}\text { d) COVID-19 Total } \\
\text { deaths until } \\
\text { 20th July } 2020\end{array}$ \\
\hline 100 & $\mathrm{CPV}$ & Cabo Verde & 555,988 & 11.99 & 23.99 & 21 \\
\hline 101 & BRN & $\begin{array}{l}\text { Brunei } \\
\text { Darussalam }\end{array}$ & 437,483 & 9.44 & 18.88 & 3 \\
\hline 102 & ISL & Iceland & 341,250 & 7.36 & 14.72 & 10 \\
\hline 103 & BRB & Barbados & 287,371 & 6.20 & 12.40 & 7 \\
\hline 104 & SYC & Seychelles & 98,340 & 2.12 & 4.24 & 0 \\
\hline \multicolumn{3}{|c|}{ Grand total } & $5,014,587,129$ & 108,185 & 216,369 & 571,694 \\
\hline
\end{tabular}

Note: One unit of days from Jan 1 until first case increase leads to 3.082 units of deaths per million increase based on the sample of 104 countries in Table 7, the calculation formula is: $3.082 /$ million*days delay*population

216,369 (14-day delay), respectively. The 7-day delay figure is a hypothetical implicit finding based on the present study and in most industrialized countries the number of lives saved from postponing the first infections by one week indeed makes sense (e.g., 5\% in the US; 5\% in France, 4\% in Italy and Spain, 9\% in Canada - based on total COVID-19 fatalities recorded as of July 20, 2020). In countries with very low number of fatalities officially recorded - often obviously standing for underreporting in many developing countries - or in economies where the peak of the infection is still several months away, the implicit figure for lives saved as a result of a 7-day delay could exceed the actual number of fatalities by the reference date of July 20 . However, the approach itself remains a useful analytical exercise and by the end of 2020 more countries with meaningful (post-peak) results should be also be recorded in the socalled South of the world economy. Lower fatality rates typically mean less problems for the relevant health care system and certainly also welfare gains; in terms of the economic effects, a lower fatality figure could not only mean higher effective employment figures in the medium term and long run but also less of a negative psychological "scarring effect" in the population which undermines consumption demand. Countries with a relatively early and focused epidemic policy have thus recorded considerable gains by saving lives. Countries with greatly reduced fatality figures (in the case of delaying infections) from the same region would have benefitted jointly from a lower reduction of trade, foreign investment and output if one follows the logic of the gravity equation for trade and foreign direct investment.

Acknowledgments We gratefully acknowledge research support by David Hanrahan (EIIW/University of Wuppertal). For discussion we should like to express our gratitude to Werner Roeger, European Commission, for communication on fatality aspects; our thanks also go to Helmut Brunner, University of Wuppertal, for pointing out ARDS and MRSA problems. The usual disclaimer applies.

Funding Open Access funding enabled and organized by Projekt DEAL. 
Open Access This article is licensed under a Creative Commons Attribution 4.0 International License, which permits use, sharing, adaptation, distribution and reproduction in any medium or format, as long as you give appropriate credit to the original author(s) and the source, provide a link to the Creative Commons licence, and indicate if changes were made. The images or other third party material in this article are included in the article's Creative Commons licence, unless indicated otherwise in a credit line to the material. If material is not included in the article's Creative Commons licence and your intended use is not permitted by statutory regulation or exceeds the permitted use, you will need to obtain permission directly from the copyright holder. To view a copy of this licence, visit http://creativecommons.org/licenses/by/4.0/.

\section{References}

Adhikari A, Yin J (2020) Short-term effects of ambient ozone, PM2.5, and meteorological factors on COVID19 confirmed cases and deaths in Queens, New York. Int J Environ Res Public Health 17(11):4047. https://doi.org/10.3390/ijerph17114047

Aliberti S, Reyes LF, Faverio P, Sotgiu G, Dore S, Rodriguez AH, Soni NJ, Restrepo MI, Aruj PK, Attorri S, Barimboim E, Caeiro JP, Garzón MI, Cambursano VH, Ceccato A, Chertcoff J, Lascar F, di Tulio F, Cordon Díaz A, de Vedia L, Ganaha MC, Lambert S, Lopardo G, Luna CM, Malberti AG, Morcillo N, Tartara S, Pensotti C, Pereyra B, Scapellato PG, Stagnaro JP, Shah S, Lötsch F, Thalhammer F, Vincent JL, Anseeuw K, Francois CA, van Braeckel E, Djimon MZ, Bashi J, Dodo R, Aranha Nouér S, Chipev P, Encheva M, Miteva D, Petkova D, Balkissou AD, Pefura Yone EW, Mbatchou Ngahane BH, Shen N, Xu JF, Bustamante Rico CA, Buitrago R, Pereira Paternina FJ, Kayembe Ntumba JM, Vladic Carevic V, Jakopovic M, Jankovic M, Matkovic Z, Mitrecic I, Bouchy Jacobsson ML, Bro Christensen A, Heitmann Bødtger UC, Meyer CN, Vestergaard Jensen A, Baunbæk-knudsen G, Trier Petersen P, Andersen S, elSaid Abd el-Wahhab I, Elsayed Morsy N, Shafiek H, Sobh E, Abdulsemed KA, Bertrand F, BrunBuisson C, de Montmollin E, Fartoukh M, Messika J, Tattevin P, Khoury A, Ebruke B, Dreher M, Kolditz M, Meisinger M, Pletz MW, Hagel S, Rupp J, Schaberg T, Spielmanns M, Creutz P, Suttorp N, Siaw-Lartey B, Dimakou K, Papapetrou D, Tsigou E, Ampazis D, Kaimakamis E, Bhatia M, Dhar R, D'Souza G, Garg R, Koul PA, Mahesh PA, Jayaraj BS, Narayan KV, Udnur HB, Krishnamurthy SB, Kant S, Swarnakar R, Limaye S, Salvi S, Golshani K, Keatings VM, Martin-Loeches I, Maor Y, Strahilevitz J, Battaglia S, Carrabba M, Ceriana P, Confalonieri M, d'Arminio Monforte A, del Prato B, de Rosa M, Fantini R, Fiorentino G, Gammino MA, Menzella F, Milani G, Nava S, Palmiero G, Petrino R, Gabrielli B, Rossi P, Sorino C, Steinhilber G, Zanforlin A, Franzetti F, Carugati M, Morosi M, Monge E, Carone M, Patella V, Scarlata S, Comel A, Kurahashi K, Aoun Bacha Z, Barajas Ugalde D, Ceballos Zuñiga O, Villegas JF, Medenica M, van de Garde EMW, Raj Mihsra D, Shrestha P, Ridgeon E, Ishola Awokola B, Nwankwo ONO, Olufunlola AB, Olumide S, Ukwaja KN, Irfan M, Minarowski L, Szymon S, Froes F, Leuschner P, Meireles M, Ferrão C, Leuschner P, Neves J, Ravara SB, Brocovschii V, Ion C, Rusu D, Toma C, Chirita D, Dorobat CM, Birkun A, Kaluzhenina A, Almotairi A, Bukhary ZAA, Edathodu J, Fathy A, Mushira Abdulaziz Enani A, Eltayeb Mohamed N, Ulhadi Memon J, Bella A, Bogdanovic N, Milenkovic B, Pesut D, Borderìas L, Bordon Garcia NM, Cabello Alarcón H, Cilloniz C, Torres A, Diaz-Brito V, Casas X, Encabo González A, Fernández-Almira ML, Gallego M, Gaspar-García I, González del Castillo J, Javaloyes Victoria P, Laserna Martínez E, Malo de Molina R, Marcos PJ, Menéndez R, Pando-Sandoval A, Prat Aymerich C, Lacoma de la Torre A, García-Olivé I, Rello J, Moyano S, Sanz F, Sibila O, Rodrigo-Troyano A, Solé-Violán J, Uranga A, van Boven JFM, Vendrell Torra E, Pujol JA, Feldman C, Kee Yum H, Fiogbe AA, Yangui F, Bilaceroglu S, Dalar L, Yilmaz U, Bogomolov A, Elahi N, Dhasmana DJ, Feneley A, Ions R, Skeemer J, Woltmann G, Hancock C, Hill AT, Rudran B, Ruiz-Buitrago S, Campbell M, Whitaker P, Youzguin A, Singanayagam A, Allen KS, Brito V, Dietz J, Dysart CE, Kellie SM, Franco-Sadud RA, Meier G, Gaga M, Holland TL, Bergin SP, Kheir F, Landmeier M, Lois M, Nair GB, Patel H, Reyes K, Rodriguez-Cintron W, Saito S, Soni NJ, Noda J, Hinojosa CI, Levine SM, Angel LF, Anzueto A, Whitlow KS, Hipskind J, Sukhija K, Totten V, Wunderink RG, Shah RD, Mateyo KJ, Noriega L, Alvarado E, Aman M, Labra L (2016) Global initiative for methicillin-resistant Staphylococcus aureus pneumonia (GLIMP): an international, observational cohort study. Lancet Infect Dis:1364-1376. https://doi.org/10.1016/S1473-3099(16)30267-5

ARD (2020) Von den Toten lernen [Transl.: Learn from the dead], dated April 21 2020, available at https://www.tagesschau.de/investigativ/ndr-wdr/corona-obduktionen-103.html 
Asian Development Bank (2020), An updated assessment of the economic impact of COVID-19, ADB Briefs No 133, https://doi.org/10.22617/BRF200144-2

Bank of England (2020) Monetary policy report, May 2020, London

Bansal S, Zilberman D (2020) Macrorelationship between average life expectancy and prevalence of obesity: theory and evidence from global data. Agric Econ 51(3):403-427. https://doi.org/10.1111/agec.12562

Beisel K (2020) Der Verdacht genügt; Die Sterberate im Land ist außergewöhnlich hoch. Das liegt vor allem daran, wie Belgien seine Corona-Toten zählt. Diese Praxis führt nun zu Unmut in der Politik [Transl: The suspicion is sufficient; the death rate in the county is unusually high. That is primarily due to how Belgium counts its corona dead. The practice has led to political discontent] in Sueddeutsche Zeitung, online edition, 22. April 2020, available at https://www.sueddeutsche.de/politik/belgien-der-verdachtgenuegt-1.4884888 last accessed 08.06.2020

Bhatt J, Parikh PD (2020) Is COVID-19 even subject to herd immunity? abcNEWS, dated July 8, 2020, available at https://abcnews.go.com/US/vaccine-reach-herd-immunity-scientists/story?id=71662733 (Last Accessed 21 Aug 2020)

Bretschger L, Vinogradova A (2017) Human development at risk: economic growth with pollution-induced health shocks. Environ Resour Econ 66:481-495. https://doi.org/10.1007/s10640-016-0089-0

Bretschger L, Vinogradova A (2019) Best policy response to environmental shocks: building a stochastic framework. J Environ Econ Manag 97:23-41. https://doi.org/10.1016/j.jeem.2017.07.003

Bretschger L, Grieg E, Welfens PJJ, Xiong T (2020) Corona fatality development and the environment: empirical evidence for OECD countries, economics working paper series, Vol. 20/336, Zurich: CER-ETH - Center of Economic Research at ETH Zurich, 2020 https://doi.org/10.3929/ethz-b-000419850

Chen Y, Jiao J, Bai S, Lindquist J (2020) Modeling the spatial factors of COVID-19 in New York City, SSRN.COM preprint research paper (Elsevier), Accessed 5 June 2020

Conticini E, Frediani B, Caro D (2020) Can atmospheric pollution be considered a co-factor in extremely high level of SARS-CoV-2 lethality in northern Italy? Environ Pollut 261:114465. https://oi.org/10.1016/j. envpol.2020.114465

Cui Y, Zhang ZF, Froines J, Zhao J, Wang H, Yu SZ, Detels R (2003) Air pollution and case fatality of SARS in the People's republic of China: an ecologic study. Environ Health: Glob Access Sci Sourc 2:15 https://ehjournal.biomedcentral.com/articles/10.1186/1476-069X-2-15

Deryugina T, Heutel G, Miller NH, Molitor D, Reif J (2019) The mortality and medical costs of air pollution: evidence from changes in wind direction. Am Econ Rev 109(12):4178-4219. https://doi.org/10.1257 /aer.201802794178

Dong E, Du H, Gardner L (2020) An interactive web-based dashboard to track COVID-19 in real time. Lancet Infectious Diseases, published online Feb 19, 2020 https://doi.org/10.1016/S1473-3099(20)30120-1

Economist, The (2020) When covid-19 deaths are analysed by age, America is an outlier, The Economist online, June 24, 2020, https://www.economist.com/graphic-detail/2020/06/24/when-covid-19-deaths-areanalysed-by-age-america-is-an-outlier (Last Accessed 13 Jul 20)

Esteves R, Sussman N (2020) Corona spreads to emerging markets, in COVID-19 in developing countries, Djankov, S. and Panizza, U. (Eds.), The graduate Institute of International and Development Studies, Geneva and VoxEU.org, CEPR Press: London, 362-373

EuroMOMO (2020a) EuroMOMO Bulletin, Week 18, 2020 https://www.euromomo.eu/bulletins/2020-18

EuroMOMO (2020b) Graphs and maps, Week 19, $2020 \mathrm{https} / /$ www.euromomo.eu/graphs-and-maps/

European Commission (2020) European Economic Forecast, Spring 2020, Institutional Paper No. 125, May 2020, Brussels

European Council (2020) European Council conclusions, Special European Council, 17-21 July 2020, available at https://www.consilium.europa.eu/media/45109/210720-euco-final-conclusions-en.pdf. Accessed 2 Sept 2020

Evans MF, Smith VK (2005) Do new health conditions support mortality-air pollution effects? J Environ Econ Manag 5:496-518. https://doi.org/10.1016/j.jeem.2005.04.002

Gutierrez M-J (2008) Dynamic inefficiency in an overlapping generation economy with pollution and health costs. J Publ Econ Theor 10(4):563-594. https://doi.org/10.1111/j.1467-9779.2008.00377.x

Hale T, Webster S, Petherick A, Phillips T, Kira B (2020) Oxford COVID-19 government response tracker. Blavatnik School of Government

He G, Fanb M, Zhou M (2016) The effect of air pollution on mortality in China: evidence from the 2008 Beijing Olympic games. J Environ Econ Manag 79:18-19. https://doi.org/10.1016/j.jeem.2016.04.004

HM Government (2020) Public Health: Sources and Effects of PM2.5, https://laqm.defra.gov.uk/publichealth/pm25.html 
Holtemöller O (2020) Integrated assessment of epidemic and economic dynamics, IWH Discussion Papers, No. 4/2020, Leibniz-Institut für Wirtschaftsforschung Halle (IWH), Halle (Saale). http://nbn-resolving. de/urn:nbn:de:gbv:3:2-11967

IMF (2020a) World economic outlook, April, International Monetary Fund, Washington DC

IMF (2020b) World economic outlook, June Update, International Monetary Fund, Washington DC

ISTAT (2020) Istituto Nazionale di Statistica, Impatto dell'Epidemia COVID-19 Sulla Mortalità Totale Della Popolazione Residente - primo trimestre 2020 [Tranls.: The effect of the COVID-19 epidemic based on the total death rate of the resident population - first quarter 2020], dated May 4 2020, available at https://www.epicentro.iss.it/coronavirus/pdf/Rapporto_Istat_ISS.pdf

JHU (2020) Johns Hopkins University, Whiting School of Engineering, Public health, COVID-19 Map FAQs, available at https://systems.jhu.edu/research/public-health/2019-ncov-map-faqs/

Manski CF, Molinari F (2020) Estimating the COVID-19 infection rate: anatomy of an inference problem. J Econ. https://doi.org/10.1016/j.jeconom.2020.04.041

Pfeiffer P, Röger W, in’t Veld J (2020) The COVID19-Pandemic in the EU: Macroeconomic Transmission and Economic Policy Response , In B. W. di Mauro \& C. Wyplosz, eds., 'Covid Economics, Vetted and Real-Time Papers', 30, CEPR Press

Sherpa D (2020) Estimating impact of austerity policies in COVID-19 fatality rates: examining the dynamics of economic policy and case fatality rates (CFR) of COVID-19 in OECD countries, preprint https://doi. org/10.1101/2020.04.03.20047530

Spinney L (2017) The Spanish flu of 1918 and how it changed the world. London Vintage Publishing, London

Summers L (2020) Larry Summers: COVID-19 and the global economy, Bendheim Center for Finance, Princeton University https://bcf.princeton.edu/event-directory/covid19_18/(Last Accessed 1 Jul 2020)

Sun P, Lu X, Xu C, Sun W, Pan B (2020) Understanding of COVID-19 based on current evidence. J Med Virol, first published online 25 February 2020 https://doi.org/10.1002/jmv.25722

Wang M, Zhao J, Bhattacharyad J (2015) Optimal health and environmental policies in a pollution-growth nexus. J Environ Econ Manag 71:160-179. https://doi.org/10.1016/j.jeem.2015.02.006

Wang M, Aaron CP, Madrigano J, Hoffman EA, Angelini E, Yang J, Laine A, Vetterli TM, Kinney PL, Sampson PD, Sheppard LE, Szpiro AA, Adar SD, Kirwa K, Smith B, Lederer DJ, Diez-Roux AV, Vedal S, Kaufman JD, Barr RG (2019) Association between long-term exposure to ambient air pollution and change in quantitatively assessed emphysema and lung function. JAMA 322(6):546-556. https://doi. org/10.1001/jama.2019.10255

Wang W, Tang J, Wei F (2020) Updated understanding of the outbreak of 2019 novel coronavirus (2019-nCoV) in Wuhan, China. J Med Virol, first published online 29 January 2020 https://doi.org/10.1002/jmv.25689

Welfens PJJ (2019) The global trump - structural US populism and economic conflicts with Europe and Asia. Palgrave Macmillan, London

Welfens PJJ (2020a) Macroeconomic and health care aspects of the coronavirus epidemic: EU, US and global perspectives. Int Econ Econ Policy (2) https://doi.org/10.1007/s10368-020-00465-3

Welfens PJJ (2020b) Trump's trade policy, BREXIT, Corona dynamics, EU crisis and declining multilateralism, EIIW Discussion Paper No. 276, European Institute for International Economic Relations (EIIW)/ University of Wuppertal, forthcoming

WHO (2020a) Coronavirus disease (COVID-2019) situation report 1, January 21, 2020, World Health Organization: Geneva https://www.who.int/docs/default-source/coronaviruse/situationreports/20200121-sitrep-1-2019-ncov.pdf?sfvrsn=20a99c10_4

WHO (2020b) WHO director-General's statement on IHR emergency committee on novel coronavirus (2019nCoV), dated 30 January 2020, available at https:/www.who.int/dg/speeches/detail/who-director-generals-statement-on-ihr-emergency-committee-on-novel-coronavirus-(2019-ncov)

WHO (2020c) WHO director-General's opening remarks at the media briefing on COVID-19, dated 11 March 2020, available at https:/www.who.int/dg/speeches/detail/who-director-general-s-openingremarks-at-the-media-briefing-on-covid-19\%2D\%2D-11-march-2020

WHO (2020d) Coronavirus disease (COVID-19) situation report - 106, May 5, 2020, World Health Organization: Geneva https://www.who.int/docs/default-source/coronaviruse/situation-reports/20200505 covid-19-sitrep-106.pdf?sfvrsn=47090f63_2

WHO (2020e) Coronavirus disease (COVID-2019) situation report 171, July 9, 2020, World Health Organization: Geneva https://www.who.int/docs/default-source/coronaviruse/situationreports/20200709-covid-19-sitrep-171.pdf?sfvrsn=9aba7ec7_2

WHO (2020f) Coronavirus disease (COVID-19) situation report 193, August 3, 2020, World Health Organization: Geneva https://www.who.int/docs/default-source/coronaviruse/situationreports/20200803-covid-19-sitrep-196-cleared.pdf?sfvrsn=8a8a3ca4_6 
WHO (2020g) Smoking and COVID-19: scientific brief, dated 23 August 2020, available at https://www.who. int/publications/i/item/WHO-2019-nCoV-Sci_Brief-Smoking-2020.2

World Bank (2020) The global economic outlook during the COVID-19 pandemic: a changed world. World Bank Group, Washington DC

Wu X et al. (2020) Exposure to air pollution and COVID-19 mortality in the United States, preprint, Department of Biostatistics, Harvard T.H. Chan School of Public Heath, Boston, MA https://doi. org/10.1101/2020.04.05.20054502 (Version: April 27, 2020; Last Accessed 13 Jul 20)

Publisher's note Springer Nature remains neutral with regard to jurisdictional claims in published maps and institutional affiliations.

\section{Affiliations}

\section{Lucas Bretschger $^{1} \cdot$ Elise Grieg $^{1} \cdot$ Paul J. J. Welfens $^{2} \cdot$ Tian Xiong $^{2}$}

Lucas Bretschger

lbretschger@ethz.ch

Elise Grieg

egrieg@ethz.ch

Tian Xiong

xiong@eiiw.uni-wuppertal.de

1 ETH Zurich, Zurich, Switzerland

2 EIIW/University of Wuppertal, Wuppertal, Germany 